\title{
LA SITUACIÓN POLÍTICA DE ESPAÑA EN 1821 EVOCADA EN EL DIARIO PARISINO JOURNAL DES VILLES ET DES CAMPAGNES ET LA FEUILLE PARISIENNE, RÉUNIS
}

\section{THE POLITICAL SITUATION OF SPAIN IN 1821 EVOKED IN THE PARISIAN NEWSPAPER JOURNAL DES VILLES ET DES CAMPAGNES ET LA FEUILLE PARISIENNE, RÉUNIS}

\author{
Jean-René Aymes \\ Université de la Sorbonne Nouvelle/París III
}

SUMARIO: I. INTRODUCCIÓN.- 1.1. El sitio ocupado por España en el Journal y los orígenes de las noticias - 1.2. El posicionamiento del Journal y la terminología.- II. FERNANDO VII Y SU FAMILIA.- 2.1. Las modalidades de existencia.- 2.2. La reina y el infante Don Carlos.- 2.3. La popularidad del monarca y sus tomas de posición. III. EL MINISTERIO, LAS CORTES, LOS PARTIDOS Y LAS SOCIEDADES PATRIÓTICAS. 3.1. El ministerio. 3.2. Las Cortes. 3.3. Los partidos. 3.4. Los Comuneros. 3.5. Las sociedades patrióticas.IV. LOS LIBERALES.- 4.1. Su doctrina.- 4.2. Su actuación y la represión que ejercen. 4.3. Rafael del Riego.- 4.4. Francisco Espoz y Mina. - V. LOS REALISTAS Y LOS "SERVILES".- 5.1. Las bases doctrinales.- 5.2. La lucha organizada. 5.3. Jerónimo Merino.- VI. LOS MILITARES.- VII. EL CLERO Y LA RELIGIÓN.- 7.1. La actuación pacífica del clero. 7.2. El clero como víctima. VIII. LOS ESPAÑOLES REFUGIADOS EN FRANCIA.- IX. LA OPINIÓN PÚBLICA, LA PALABRA ORAL Y ESCRITA.- 9.1. La prensa. 9.2. La literatura. 9.3. El teatro y las canciones. X. LA SITUACIÓN GENERAL.- 10.1. La economía. 10.2. La epidemia de fiebre amarilla. XI. EL MUNDO EXTERIOR VISTO DESDE ESPAÑA.

Resumen: En este texto se analiza un diario parisino poco conocido que evoca la España de 1821, pero no lo hace de manera neutral, sino desde la posición ideológica de ser monárquico, conservador y clerical. Los articulistas llegan a admitir que, viéndose gravemente amenazado, el monarca ha accedido por obligación a prometer ser fiel al nuevo régimen y a la Constitución. En sus páginas se juzga favorablemente a los absolutistas (los "serviles"), al clero y a los "guardias de corps" del rey. Los adversarios aborrecidos son los "comuneros", los miembros de las "Sociedades Patrióticas", los militantes de la "Fontana de Oro" y los liberales "exaltados", a veces tachados de "revolucionarios". Según el Journal, con los partidarios ineptos del "nuevo sistema", se agrava la economía en todos los sectores.

Abstract: This text analyzes a little-known Parisian newspaper that evokes the Spain of 1821, and does not do so in a neutral way, but from the ideological position of being monarchist, conservative and clerical. The columnists come to admit that, seeing himself seriously threatened, the monarch has agreed by obligation to promise to be faithful to the new regime and the Constitution. In its pages the absolutists (the "servile"), the clergy and the "guardias de corps" of the king are judged favorably. The hated adversaries are the "commoners", the 
members of the "Patriotic Societies", the militants of the "Fontana de Oro" and the "exalted" liberals, sometimes labeled as "revolutionaries." According to the Journal, with the inept supporters of the "new system," the economy is worsening in all sectors.

Palabras clave: Constitución, Contrarrevolución, Liberal, Madrid, Rey (el)

Key words: Constitution, Counterrevolution, Liberal, Madrid, The King

\section{INTRODUCCIÓN}

\subsection{El sitio ocupado por España en el Journal y los origenes de las noticias}

Como lo anuncia el título del Journal, se advierte el predominio abrumador de lo que se refiere a Francia con la exposición y los comentarios de los acontecimientos políticos, de la religión, de las obras impresas y de los pequeños sucesos ("faits divers" en francés) ${ }^{1}$.

España y otros países figuran bajo el título "Noticias extranjeras" ("Nouvelles étrangères" en francés). Corresponden casi todas a Europa: Inglaterra, Alemania, Austria, Rusia, Portugal y apenas América. Asia y África están casi totalmente ausentes. España ocupa el primer puesto en 1821, aunque menos que en los comienzos de 1820 después de la revolución llevada a cabo por Riego, pero luego aumenta el interés en la víspera de la intervención de los "Cien Mil Hijos de San Luis" en 1823.

En la mayoría de ellas aparece la mención de la ciudad: Madrid, Barcelona, Zaragoza, Irún, Tortosa, Bayona. A pesar de la importancia de los acontecimientos localizados en Cádiz, Sevilla y Valencia, sólo de manera indirecta se alude a esas tres ciudades. Por supuesto, predomina Madrid.

La casi totalidad de los textos son anónimos. Algunos llevan el rótulo "Correspondencia particular" o la mención "Según nuestro corresponsal» o "Carta llegada por una vía extraordinaria".

El origen español, real o fingido, parece atestiguado por expresiones tales como "notre malheureuse Espagne" o "Moi-même, j'ai entendu dire à des membres de la Fontana de Oro...". Una cantidad inferior de noticias procede de Francia, por ejemplo cuando se lee: "On nous écrit de Bayonne...". Otras están sacadas directa o indirectamente de diarios o de semanales, como el Journal de Perpignan, el Journal de Paris, la Ruche d'Aquitaine, le Mémorial Béarnais.

1 En la Biblioteca Nacional parisina los números accesibles del Journal van desde el $\mathrm{n}^{\circ} 2$ (falta el $n^{\circ}$ 1) del 6 de enero de 1821 hasta el final del siglo XIX. Pero el Journal ya existía en 1820 a partir del $1^{\circ}$ de julio. Los dos viejos estudios dedicados a la prensa francesa, redactados por Eugène Hatin en 1967 y por Bellanger en 1969 cubren los años desde 1849 hasta 1871, pero son, para mí, años demasiado tardíos. En cuanto a Bellanger, se trata de la Histoire générale de la presse française, publiée sous la direction de Claude Bellanger, Jacques Godechot, Pierre Guiral, Fernand Terrou, 5 vol., Paris, Presses Universitaires de France, 1969-1976. No disimulo el inconveniente de ignorar la identidad del responsable o de los articulistas del Journal.

A lo largo de mi artículo se lo mencionará en francés bajo el título abreviado de Journal. Las referencias cronológicas de los artículos remiten al número del Journal (ejemplo: 21 de octubre) y no a la fecha ocasional de su origen en España (ejemplo: «Madrid, 15 octubre»). 
Algunos textos extensos publicados en castellano en España se transcriben a veces integramente en francés. Se trata, por ejemplo, de varios discursos de Fernando VII ( $1^{\circ}$ de mayo, 12 de julio), de una proclama del jefe político de Madrid (16 de agosto), de otra de Merino (4 de julio), de un discurso pronunciado en la Fontana de Oro (4 de diciembre).

\subsection{El posicionamiento del Journal y la terminologia}

El diario se aparta ostensiblemente de la neutralidad y de la imparcialidad. Como lo veremos cuando se examine el enfoque siempre halagüeño del rey Fernando VII, el Journal es monárquico y vehementemente antirrepublicano. Su moderación le incita a imputar a los "revolucionarios" españoles la guerra civil, los disturbios, la anarquía y las venganzas. En cambio, su antiliberalismo no es indiferenciado, ya que se juzga con cierta indulgencia a los liberales sensatos y moderados, mientras que los "jacobinos" suscitan el aborrecimiento.

La oposición al "nuevo sistema" (sic) le lleva a justificar la guerrilla absolutista fomentada por los "realistas", a veces designados por los partidarios del nuevo régimen con el término infamante de "serviles". De manera general, se alaba al pueblo español por su moderación y su cordura, mientras que el "populacho" fomenta el odio, o el desprecio, o el temor.

Se puede calificar el Journal de católico y de clerical, en particular cuando como veremos al final-, los eclesiásticos se portan con generosidad durante la mortifera epidemia de fiebre amarilla en Barcelona y su comarca. La total politización del enfoque de los habitantes excluye la evocación de su vida cotidiana, de sus aspectos exteriores, del folklore, de los monumentos, del paisaje. Nada anuncia el inicio de la moda española, propia de una época posterior (después de 1823) y del romanticismo ${ }^{2}$.

El investigador lamentará la frecuente alteración de los apellidos cuando se lee, por ejemplo, "Nunes-Abreu" en lugar de "Núñez Abreu". La alteración es mínima cuando la Fontana de Oro se convierte en "Fontana d'Oro". Por otro lado, la acentuación suele ser caprichosa como, por ejemplo, "Cortès" y "liberalès".

A veces, la conversión al francés de un enunciado en castellano engendra un neologismo, tal como "junte apostolique» en Galicia; pero no está excluido que el término "junte" ya se haya empleado en Francia entre 1808 y 1814 para aludir a la Junta Central o a una junta local creada por los adversarios de los ejércitos napoleónicos.

En algunos casos se agradece el esfuerzo destinado a proporcionar el equivalente en francés de un término castellano ignorado por la mayoría de los súbditos de Luis XVIII. Por ejemplo, el término "descamisados" viene acompañado útilmente del paréntesis "sans chemise, sans-culottes".

Raras veces se transcribe en castellano, sin traducción, expresiones, como el grito "matar, degollar a los traidores". En cambio, la Guerra Gran (1793-1795) y la Guerra de la Independencia habian exportado a Francia términos tales como "guerilla" o "guérilla", pero sin la doble r.

2 Cf., por ejemplo, Bory de Saint-Vincent, Guide du voyageur en Espagne, Paris, Librairie Louis Janet, 1823. 
Más de una vez, se podría lamentar el olvido de las comillas que hubieran revelado el carácter específico de tal o cual término español, por ejemplo, en el caso de "chef politique" que, entonces, no se empleaba en Francia.

\section{FERNANDO VII Y SU FAMILIA}

\subsection{Las modalidades de existencia}

Curiosamente, la aparición del monarca en 1821es tardía, puesto que sólo figura en el número del 11 de marzo, pero con la mención "Madrid (Espagne, 26 février". Las noticias pertenecen a dos clases: una -que se examinará ulteriormente- remite a su actuación en las Cortes, mientras que, en la segunda, se perfila la imagen embellecedora de un monarca vinculado a sus súbditos, aunque no todos sean respetuosos. En efecto, en esos momentos, estando enfermo, no podía mostrarse en el balcón del palacio, pero se vio obligado a asomarse para poner término a unos "rumores ridículos" que le achacaban una enfermedad fingida:

(E1 rey) no ha salido ni el sábado ni el domingo porque el viernes fue insultado más allá de la puerta de Alcalá, en el camino hacia el Retiro. Se le cantó una canción terrible contra los Borbones. Cuando volvió al palacio, aunque quedaba poca gente en la plaza, fue recibido con gritos de odio y con la misma canción.

Unos dias después, se anuncia en el diario que el rey lleva varios dias sin salir del palacio por miedo a que le insulten "unos individuos del populacho" (8 de abril).

De nuevo, pero muchos meses después, a finales de agosto, se alude otra vez a su enfermedad que ha sido consecuencia de los disturbios que tenian lugar en el país. Posiblemente para escapar a los insultos, viaja al palacio de la Granja de San Ildefonso (2 de septiembre). De allí volverá a finales de septiembre (28 de septiembre). En la Granja de San Ildefonso no estará rodeado de "espías" y de "acusadores". El rey declaró: "No puedo dar un paso sin que ello se interprete de un modo atroz" (6 de septiembre). Su alejamiento de la capital también alimenta rumores malintencionados, porque "los grandes patriotas" -expresión irónicapiensan que va a "fomentar una conspiración" (10-11 de septiembre).

A mediados de septiembre, se anuncia que el rey está afectado por "ligeros sintomas de gota" (13 de septiembre). A finales de noviembre, el rey, cuya salud se ha restablecido, está en el Escorial con su familia (17-18 de diciembre). Volverá a Madrid el 4 de diciembre, cumpliendo una orden ministerial (17-18 de diciembre). A principios de diciembre, se ve obligado a ir al Prado con su familia, por medida de precaución, porque unas noticias sorprendentes crean la extraña impresión de que el palacio real podría ser atacado en "la extremidad de la ciudad", aunque ante la eventualidad de un ataque, el palacio sería fácil de defender gracias a la existencia de murallas y de subterráneos (23 de diciembre).

\subsection{La reina y el infante Don Carlos}

Sólo una vez se alude a la joven y amable "princesa de Sajonia" esposa del rey, que, en San Ildefonso, no cesa de llorar (27 de septiembre). 
A mediados de agosto, el infante Don Carlos ${ }^{3}$ proyectaba ir a Portugal para visitar a la familia de su esposa, pero se le negó el permiso, porque se consideró que, para ello, era imprescindible la autorización concedida por las Cortes. La segunda referencia a Don Carlos es de sumo interés, porque se perfilan, aunque con vaguedad e incertidumbre, sus opiniones políticas que anuncian lo que será su vehemente oposición al liberalismo después de la muerte de su padre: "Se comenta que S.A.R. el infante don Carlos se ha puesto a la cabeza de un partido compuesto de realistas y de afrancesados para derribar el sistema constitucional" (9 de septiembre).

\subsection{La popularidad del monarca y sus tomas de posición}

A principios de marzo, en un debate en las Cortes acerca de los títulos atribuidos al rey, se rechazó el concepto halagador de "padre de la patria" y se aprobó el de "Fernando VII, rey de España, por la gracia de Dios y de la Constitución" (11 de marzo).

En julio, el discurso pronunciado por el rey en la sesión de cierre de las Cortes se considera muy admirable. De manera sorprendente para el lector actual del Journal, el monarca, dirigiéndose a los diputados, formula unas alabanzas de una gran extensión y de un increíble fervor, acompañadas por la expresión de su gratitud: "Este congreso muy ilustrado ${ }^{4}$, lleno de patriotismo y de virtudes, ha dado, durante la presente legislatura, nuevas pruebas de sus esfuerzos constantes para asegurar la felicidad pública. Sus esfuerzos para concluir y perfeccionar nuestra regeneración politica han ido más allá de mis esperanzas" (12 de julio). Las mejoras del "sistema constitucional" han tenido laudables repercusiones en "la agricultura, la industria, las artes y las ciencias". El rey, con un optimismo desaforado, espera lo mismo de la legislatura siguiente. Ese discurso -en el supuesto de su autenticidad y de la fidelidad de su traducción al francés para el Journal- suscita la estupefacción del lector, porque hace del rey un entusiasta partidario del nuevo régimen y un admirador de los españoles que lo han instaurado: ¿Cómo admitir la compatibilidad entre la gratitud basada en el respeto de "la dignidad de la casa real" y los insultos que se lanzan contra el rey en las calles madrileñas? Pero es verdad que, en 1821, y más todavía en Francia que en España, no se supone que el monarca practique el doble juego y que, probablemente, estuvo obligado a leer un discurso impreso, redactado por algún ministro o por el mismo presidente de las Cortes.

En el Journal del 11 de agosto, el lector no puede entender muy bien de dónde proceden, quizás del Journal de Paris o de una información de Clausel de Coussergues, unas noticias extraordinariamente insultantes, no sólo para Fernando VII, sino también para "todos los príncipes de la familia de los

\footnotetext{
3 Cf. Las numerosas referencias a don Carlos en Emilio La Parra, Fernando VII. Un rey deseado y detestado, Barcelona, Tusquets Editores, 2018. Siquiera por la abundante bibliografia que lo acompaña, cf. también el artículo de Antonio Manuel Moral Roncal, "Don Carlos y el carlismo durante el Trienio liberal (1820-1823)", Trienio, n³6, noviembre 2000, pp. 141-160. Cf. en particular, la mención de la carta del infante don Francisco de Paula al rey, escrita el 20 de julio de 1821 , en la que le confesaba que había comenzado a escribir a su cuñada, la duquesa de Berry -ferviente contrarrevolucionaria- "solicitando la ayuda del gobierno francés para derribar el régimen constitucional" (p. 150).
}

4 En francés: "Plein de lumières". 
Borbones". En las calles se escuchó "un canto de muerte" lanzado por los revolucionarios madrileños, y transcrito groseramente: "Lairon, lairon, muero todo Borbon". A continuación, viene la traducción al francés: "ça irá, ça irá, meure tout Bourbon" (11 de agosto).

No puede sorprender que, en las Cortes, se manifiesten, con sinceridad, o con ilusión, o por táctica, unos diputados o una parte del público, que aplauden al monarca al final de su discurso y gritan "¡Viva el rey! ¡Viva el rey constitucional! ¡Vivan las Cortes y la Constitución!» (13 de octubre).

Pero el monarca suscita también opiniones violentas y contradictorias. Así, en la carta de un particular escrita en Cádiz el 22 de septiembre y dirigida al "Congreso Nacional", Fernando VII está considerado como "el más feroz de los tiranos". La gritería y los discursos más desenfrenados se oyeron alrededor del palacio real, para provocar el desorden y fomentar atentados. Afortunadamente, los ciudadanos generosos, apegados al monarca, han formado "una tropa vigilante y fiel" (29-30 de octubre).

Como si hubiera tardado en emerger la popularidad del monarca fuera de las Cortes, se la evoca por primera vez, solamente a finales de 1821 , cuando vuelve del Escorial. A lo largo de una fila formada por la milicia, los habitantes le ofrecen flores y palomas. El corresponsal se complace en observar que nunca se le había acogido con tantas demostraciones de amor. Pero llama la atención el contraste con los sentimientos intensos de odio ya señalados a partir de la primavera (1718 de diciembre). Tomando en consideración el aborrecimiento que inspira al populacho y a los revolucionarios, el rey llega a imaginar que su suerte anuncia la del infeliz Luis XVI. De ahí su declaración más heroica que patética: "Si he de morir, será con las armas en la mano y a la cabeza de mi guardia".

La primera imagen del rey en 1821 es halagüeña, porque el monarca da la impresión de querer sintonizar con los diputados tras haber recibido él con amabilidad a los representantes a finales de febrero. Ha declarado que asistirá personalmente a la apertura de las Cortes, el $1^{\circ}$ de marzo, pero espera que tomen las medidas convenientes para evitar "los escandalosos ultrajes a las que se halló expuesto en algunas ocasiones". Un poco más lejos, se transcribe, en la primera página del diario, los pasajes más admirables del discurso del monarca. Entre otros temas, se denuncia los extravios de algunos individuos malignos, deseosos de inspirar la desconfianza respecto a las intenciones puras del rey. Ahora bien, él recuerda que ha jurado la Constitución: "Debe a su dignidad y al honor de su trono el poder declarar a las potencias de Europa que no reconocerá nada que sea hostil al derecho positivo de la gente, cuando se trata de la libertad, de la independencia y de la prosperidad de las naciones". Un comentario elogioso acompaña los extractos del discurso: "Pronunciado con un acento a la vez firme y noble, ha producido un gran efecto en la asamblea, y el rey salió de la sala con una dignidad que ha impresionado a todos los presentes" (11 de marzo).

En realidad, la sumisión del rey a las iniciativas y decisiones de las Cortes y de algunos consejeros funciona con altibajos. Así, a principios de mayo, la elección de los exministros propuestos por unos consejeros de Estado no ha conseguido el beneplácito del monarca. Incluso S.M. ha hecho constar su desacuerdo cuando se le comunicó el nombre de esos personajes. Por otra parte, ha aplazado su decisión respecto al proyecto de las Cortes referido a las sociedades patrióticas (14-15 de mayo). 
A finales de agosto, el rey toma la iniciativa arriesgada de rechazar la dimisión del general Morillo, pero los lectores del Journal no entenderán tampoco yo- por qué "S.M. ordena que comparezca ante un consejo de guerra" (23 de septiembre).

No se sabe si se ha de conceder alguna credibilidad a una declaración de Ramón Feliú, ministro del Interior, que da cuenta de las opiniones del rey acerca de "los serviles (sic) que no son los peores enemigos de la Constitución; lo son los que la desacreditan y la destruyen y también los que provocan la confusión y la anarquía". O sea que el rey, sin llegar a coincidir con los ultra-absolutistas, se limita a fustigar a los revolucionarios denunciados con frecuencia por querer fomentar el desorden (27 de octubre).

"Por vía extraordinaria" llegó al Journal una carta escrita en Madrid el 27 de noviembre a propósito de los disturbios que tuvieron lugar en Cádiz. Se abrió la sesión de las Cortes con la lectura de un mensaje del rey, transcrito en su totalidad. El rey, tras lamentar esos desórdenes, no duda en proclamar, con una aparente sinceridad, su total adhesión a las Cortes; "Mis deseos son los mismos que los de las Cortes; sólo tienen por finalidad el respeto y la consolidación del sistema constitucional (...). Espero que darán a nuestra patria y a Europa un nuevo testimonio del espíritu de conciliación con España con el que se han puesto en evidencia" (7 de diciembre).

Es decir que, para los lectores del Journal, Fernando VII, a lo largo de 1821, es un modélico rey constitucional. Otra cosa es pronunciarse acerca de su sinceridad. Si me arriesgo a aclarar y sintetizar sus opiniones y su táctica a partir, exclusivamente, de la información proporcionada por el Journal, entro en un callejón sin salida, porque los datos disponibles son fragmentarios $\mathrm{y}$, peor todavia, incompatibles. Sólo adelantaré aquí algunas hipótesis frágiles que son las siguientes:

- quizás el rey, con prudencia y cierta habilidad, finge su adhesión al liberalismo;

- puede haberse visto obligado a leer en las Cortes unos discursos redactados, no por él, sino por los ministros;

- disimula que tiene muchos partidarios en el país;

- puede ser que mantenga una correspondencia secreta con notables oponentes al nuevo régimen en España y en el extranjero;

- no se ha de excluir que practique el doble juego con destreza;

- imposible calibrar la importancia cuantitativa de los súbditos que le aman y de los que le aborrecen y desean su abdicación.

Aunque, en la obra de Emilio La Parra, la casi totalidad de las observaciones se refieren a los años 1822 y 1823, creo que se puede aplicar a 1821 lo que se lee en el subcapítulo titulado "Director de la contrarrevolución": "Fernando VII se colocó en el centro de las actuaciones contra el constitucionalismo, no sólo porque los comprometidos en ellas tomaron como bandera su nombre, junto con la religión, sino también porque el rey dirigió personal y directamente las acciones encaminadas a propiciar el cambio de régimen ${ }^{5}$.

${ }^{5}$ La Parra, Fernando VII, op. cit., pp. 399-407. Cita, p. 400. 


\section{EL MINISTERIO, LAS CORTES, LOS PARTIDOS Y LAS SOCIEDADES PATRIÓTICAS}

\subsection{E1 ministerio}

La mención de algunas medidas discutidas o aprobadas por los diputados contribuye a reducir, en el Journal, el papel atribuido a los ministros que parecen limitarse a reprimir a los oponentes al nuevo régimen, esencialmente ultrarrealistas y partidarios del antiguo régimen. Así, a mediados de abril, se anuncia la detención, en Barcelona, de unas veinte personas; encabeza la lista "el general barón de Eroles»; le acompañan varios generales, el obispo, el vicario general, varios canónigos y el superior de los capuchinos (20 de abril).

En Orense, los detenidos pasan varios meses en cárceles subterráneas. Se persigue sistemáticamente a la alta jerarquía del clero, y las relaciones en su seno se tachan de conspiraciones. Se suprimen los recursos de que disponían las instituciones monásticas (26 y 29 de abril). En la primavera, se critica al ministerio por no pedir el cierre de los locales frecuentados por la Fontana de Oro.

Por supuesto, dada la orientación general del Journal, se da la preferencia a la enumeración de las medidas extremas y ominosas, en menoscabo de eventuales decisiones moderadas, oportunas y populares. Según una nota procedente de Irún a principios de diciembre los habitantes que juzgan al ministerio están divididos: unos lo sostienen, otros piden la destitución de tal o cual ministro (17 de diciembre). También a principios de diciembre, se afirma en el Journal que los sevillanos, los gallegos y los catalanes han cesado de sostener al gobierno. Pero, el mismo dia, se corrige esa afirmación al escribir que, en las provincias, no existe unanimidad para pedir la destitución de los ministros (19 de diciembre).

En el Journal del 15 de diciembre se da la palabra indirectamente al "comandante general y jefe político de Cádiz, el señor Jáuregui" que ha enviado una carta al rey, otra a los ministros de la Guerra y del Interior y la tercera a la diputación permanente de las Cortes: "En la carta a S.M. acusa a los ministros de los males actuales (...). Habla de los ministros como unos tunantes que merecen la horca" (15 de diciembre) ${ }^{6}$.

\subsection{Las Cortes}

\section{Su actuación}

Pronto en 1821 y en dos ocasiones, en el Journal, se define a España como el país de las Cortes y de la Constitución. Pero esa afirmación no anuncia que se va a conceder una atención privilegiada a ese tema. Lo confirma la primera linea del artículo publicado a finales de marzo (26-27 de marzo): "Las sesiones de las Cortes siguen ofreciendo a los extranjeros muy poco interés" cuando se trata, como ahora, de las bellas artes, de las monedas y del diezmo. Por cierto, se entiende esa indiferencia cuando se alude a la hacienda o a la economía, pero

615 diciembre. Se trata de Manuel Francisco Jáuregui: Alberto Gil Novales, Diccionario biográfico de España (1808-1833). De los origenes del liberalismo a la reacción absolutista, Madrid, Fundación Mapfre, 2010, t. II, pp. 1569-1570. 
puede sorprender que a ese bajo nivel de interés se sitúen las bellas artes, lo que anuncia, pues, que "la moda española" que incluye las artes, la pintura, la música, los monumentos, etc., no apunta todavia en Francia.

Naturalmente, las menciones de las Cortes se relacionan principalmente con la alarmante actualidad política. Por ejemplo, a cierta "comisión española" está dedicada toda una columna en el Journal de los primeros días de abril, porque se trata de buscar remedios contra los atentados y contra "las tentativas contra el rey y la familia real" (2-3 de abril).

En la sesión del 14 de marzo, el Sr. "Solano»" recordó que, en una sesión en 1820 , propuso la abolición del diezmo, pero "Moreno-Guerra" ${ }^{8}$ contestó que no veía cómo sustituir los 300 o 350 millones de reales que proporcionan los diezmos. También intervino el conde de Toreno adoptando el punto de vista de "Moreno-Guerra" (30 de marzo).

Procedente de Madrid y redactada el 21 de mayo, una información, por primera vez amplia y ambiciosa, habrá dejado perplejo al lector cuando haya leído lo siguiente:

Una oposición realista-constitucional (sic) empieza a manifestarse en la opinión de las Cortes. Se espera de ellas buenos resultados. La mayoria de esa asamblea quiere la monarquía, pero está consciente de la necesidad de modificar la Constitución.

Luego viene el enunciado infundado y ahora inadmisible: «Esa mayoría no es tan atrevida como el partido dominante que anhela la república" (2 de junio). Pero no olvidemos que esa afirmación era bastante corriente, porque a los "revolucionarios" se solía achacar la voluntad de acabar con la monarquía y de instaurar una república, como hicieron los franceses en el último decenio del siglo XVIII: "La mayoría de los hombres que han celebrado por principio el establecimiento de la Constitución experimentan ahora indignación ante la inepcia de las Cortes, la inestabilidad de los ministros y el desorden general que reina en todas las ramas de la administración" (6 de septiembre).

También a finales de agosto, cuando se acerca la primera sesión de las Cortes extraordinarias, se formula el siniestro augurio de que serán incapaces de eliminar "los males espantosos que nos amenazan" (9 de septiembre). Esa primera sesión está organizada por una Junta presidida por Calatrava9.

A finales de septiembre, "la agitación es sumamente intensa en todos los partidos para conseguir nombramientos": "Desde hace mucho tiempo, algunos jefes políticos en las provincias han enviado agentes para asegurar los sufragios favorables para ellos o para sus amigos" (4 de octubre).

Renuncio a pasar revista a los debates abiertos, desde la primavera hasta el invierno, acerca de las divisiones territoriales, de los sueldos de las milicias

\footnotetext{
7 Será Valentín Solanot, diputado por Aragón: Gil Novales, op. cit., t. III, p. 2903.

8 Será José María Moreno de Guerra y Navarro, diputado por Córdoba: Gil Novales, Diccionario biográfico de España, op. cit., t. II, pp. 2080-2086.

9 José María Calatrava había presentado, en mayo, el proyecto de una "Constitución políticonatural para todos los pueblos»: Gil Novales, Diccionario biográfico de España, op. cit., t. I, pp. 529530.
} 
provinciales (4 y 15 de octubre), de los derechos señoriales, de la reducción de los diezmos, de la reorganización de las fuerzas armadas, etc.

\section{- Los oradores sobresalientes}

En varias ocasiones, se transcriben las palabras pronunciadas por el conde de Toreno, "miembro de la sección de finanzas", que encarna la moderación y que, por ese motivo, se ve atribuir por el Journal una imagen más halagüeña que repulsiva (26-27 de marzo). Por el mismo motivo, es decir la moderación y la búsqueda de la conciliación, Calatrava está bien tratado.

Ocurre lo contrario con Romero Alpuente que, en la sesión del 15 de diciembre, "expone, en un discurso muy vehemente, todas las acusaciones que apuntan a los ministros". Unos dias antes, al final de la sesión de las Cortes, el 9 de diciembre, fue festejado como un héroe, en la plaza del "Palais Législatif" (sic):

Romero Alpuente, ídolo de los liberales, salió del congreso, y la muchedumbre, en gran parte compuesta de los voceadores conocidos de la capital, le acogió en medio de los aplausos más vivos y de los jviva! Se le acompañó hasta su casa en medio de los gritos e incluso se le obligó después a mostrarse en el balcón, bajo el pretexto de agradecerle por el fervor con el que había defendido los derechos del pueblo al pedir la destitución y la puesta en acusación de los ministros" (22 de diciembre) ${ }^{10}$.

Un poco antes de ese episodio, tuvo lugar un incidente de significación ideológica distinta, pero complementaria. En efecto, mientras que los exaltados liberales o "revolucionarios"- han convertido a Romero Alpuente en objeto de culto, quizás los mismos provocan unos disturbios delante de las Cortes cuya reciente actuación censuran: "Gritos, silbidos, reniegos e imprecaciones se han proferido contra el rey, las Cortes y los ministros" (24-25 de diciembre). Es decir que esa vehemente denuncia no apunta sólo a los partidarios del antiguo régimen, sino que, en su radicalismo sin especificar, es la totalidad del nuevo régimen lo que rechazan, aunque sin soñar -diriase- con una república ${ }^{11}$.

10 En diciembre de 1822, se expresa de manera sumamente favorable Romero Alpuente, él mismo comunero: "Todos conocen los comuneros; éstos son los españoles escogidos, y siendo así, sea lo que fuese de los masones, esta unión puede ser homogénea a la parte de los comuneros, os repito que es la nata de los españoles decididos a sostener la Constitución de modo que dentro de poco todos (hasta las mujeres) serán comuneros", Historia de la revolución española y otros escritos, Madrid, Centro de Estudios Constitucionales (edición de Alberto Gil Novales), 1989, t. II, p. 39. Romero Alpuente volverá sobre el convenio laudable y provechoso entre "la sociedad de Masones y la de Comuneros, establecida la primera para el ejercicio de las virtudes y la segunda para la defensa de la Constitución". Un poco más allá, Romero Alpuente precisa los admirables objetivos que se ha fijado la sociedad de los Comuneros creada en 1821 para "defender a todo trance y por cuantos medios fuesen posible los derechos y libertades de la nación" en la que reside esencialmente la soberanía.

11 Me dejo llevar por la tentación de cometer una sorprendente y tendenciosa digresión al dar a conocer la opinión extremada de un eminente historiador español, refugiado en Francia durante el franquismo, hombre "de izquierda", prestigioso a los ojos de muchos jóvenes de mi generación: se trata de Manuel Tuñón de Lara que solía ajustar las cuentas con los historiadores pertenecientes al aborrecible bando franquista. Huelga precisar, pues, que el Trienio, comparado con la anterior "restauración del absolutismo", es exclusivamente objeto de alabanzas, enfoque totalmente antinómico con el que adoptó el Journal: "Suele hablarse del periodo liberal de 18201823 en términos de menosprecio o conmiseración. No está de más recordar que aquellos legisladores, tan a la ligera vapuleados por ciertos historiadores, cumplieron una obra de primer orden, a tono con el ritmo de la historia, cuya necesidad se vio confirmada en el transcurso del 


\subsection{Los partidos}

Sólo unas pocas veces se enumera y compara los distintos partidos que se enfrentan y tratan, o de acceder al poder, o de derribar el nuevo régimen, o de difundir su doctrina. Esos panoramas se hallan en el Journal del 3 de agosto y los 29 y 30 de octubre.

Una primera mención, a finales de enero, procedente del diario El Universal es, al mismo tiempo, muy breve y sorprendente: entre 13 individuos, hay un liberal, cuatro "serviles" y ocho indiferentes (24 de enero). A principios de agosto, todo un párrafo está dedicado a "los cinco partidos que dividen a España":

Los serviles, los cesantes (empleados bajo el régimen real), el clero regular y secular (esas tres clases de individuos siguen apegadas a los principios de la antigua monarquia), los afrancesados (constitucionales moderados) partidarios del sistema representativo con la realeza ${ }^{12}$ como poder, los constitucionales según el principio de las Cortes y, por fin, los jacobinos según las modalidades de 1795 (3 de agosto).

Los "Extractos de una carta particular escrita en Madrid el 18 de octubre proporcionan más noticias detalladas acerca de seis partidos (29-30 octubre): "Uno de los partidos que más se agitan es el de los communeros (sic) o demócratas sospechados de querer una república». Parecerá extraño que, en segundo lugar, aparezcan los militares que "tienen pocas ideas politicas, pero que están unidos por su entusiasmo ante la revolución de 1820, quizás por miedo a los castigos que una contrarrevolución podría acarrear para un gran número de oficiales".

Aunque no se especifica su doctrina, parece evidente que "el partido ministerial y el de las Cortes" están compuestos por liberales: "El partido ministerial que se empeña en poner en obra exactamente la Constitución está dividido en tantas camarillas ${ }^{13}$ como hay hombres notables gracias a su fama a menudo poco merecida".

El autor resalta las irremediables disensiones entre los grupos de liberales ${ }^{14}$ :

En general, no hay ningún hombre superior, ni entre los constitucionales, ni entre los comuneros, ni en las Cortes. Esos partidos no pueden ponerse de acuerdo y ninguno de ellos tiene la fuerza necesaria para triunfar de los otros y conservar el fruto de la victoria.

siglo". A continuación, viene la enumeración de las laudables medidas tomadas en los dominios del Código Penal, de la Instrucción Pública, de la administración, de las finanzas, etc. Manuel Tuñón de Lara, La España del siglo XIX (1808-1914), París, rue de Seine, Librería Española, 1971 , pp. 44-45.

12 Traducción literal del francés "royauté" que corresponde más bien al castellano "monarquía".

13 En francés: "Côteries".

14 Sobre la escisión entre los "exaltados" y los moderados, cf. en particular (clasificación cronológica): José Luis Comellas García-Llera, El trienio constitucional, Madrid, Ediciones Rialp, 1963, pp. 157-172. A. Gil Novales, El Trienio liberal, op. cit., 1980, pp. 20-22. Antonio Elorza, La modernización politica en España: ensayos de historia del pensamiento político, Madrid, Endymion, 1990, pp. 141-236, con muchas referencias a la prensa: El Censor, El Imparcial, Gazeta de Madrid. Javier Fernández Sebastián y Juan Francisco Fuentes (dirs.), Diccionario politico y social del siglo XIX español, Madrid, Alianza Editorial, 2002, pp. 413-420. 
Llama la atención la cifra muy alta, indiscutiblemente excesiva e inadmisible, según la cual "las nueve décimas de la nación corresponden a los serviles"; éstos desean la vuelta al "antiguo estado de prosperidad bajo la monarquía». Pero el autor del artículo, tomando partido, lamenta los abusos que han mancillado "el poder absoluto" durante los seis años entre 1814 y 1820.

"Los hombres de talento" se hallan en la clase de los Afrancesados, pero los constitucionales no se atreven a acudir a ellos, por miedo a las protestas de los "ultraliberales»: "El único partido enérgico es el del clero que se puede honrar de contar en su seno más de un Merino y de haber contado a más de 40 curas y monjes víctimas de los defensores de la constitución». Pero, sorprendentemente, se pasa por alto el compromiso proclamado o solapado, de carácter ideológico, de los eclesiásticos -prelados, párrocos y monjes- que siguen ejerciendo su sacerdocio sin exponerse a represalias.

\subsection{Los Comuneros}

A excepción de la breve alusión -ya señalada- a los "communeros" (sic) ${ }^{15}$ calificados de "puros demócratas", la única referencia interesante y detallada a esa "secta" (sic) se halla en un artículo fechado a principios de julio (19 de julio), alimentado por un vehemente aborrecimiento:

Una facción, aún más temible que la de los liberales ${ }^{16}$ que han iniciado la revolución, inquieta mucho al gobierno; los liberales comuneros es una secta que se puede comparar con la de los carbonari de Nápoles y que se ha expandido por Madrid, por las provincias y sobre todo por Galicia y Cataluña. No sólo predican todos la independencia absoluta frente al rey y al gobierno, sino que se atribuyen una libertad absoluta para obrar contra ellos. Son sedientos de sangre y enemigos ensañados de los serviles. Esos liberales comuneros espantan a todos los hombres honrados. El gobierno prohíbe en vano sus reuniones; desafian su autoridad o, mejor dicho, su debilidad. El centro de la asociación está en Madrid. Es una logia masónica regular que mantiene una correspondencia continua con las logias y los clubs de las provincias e incluso del extranjero.

A mediados de septiembre, se denuncia de nuevo en el Journal la detestable alianza entre los Comuneros y los masones: "Ya no hay duda de que los

15 Sobre los Comuneros, véase en particular (clasificación cronológica): Antonio Alcalá Galiano, "Memorias de D. Antonio Alcalá Galiano publicadas por su hijo", en Obras escogidas de Don Antonio Alcalá Galiano, Madrid, B.A.E, tomo LXXXIV (II), 1955, pp. 208-209. Iris M. Zavala, Masones, comuneros y carbonarios, Madrid, Siglo XXI de España Editores, 1971, pp. 72-92. A. Gil Novales, El Trienio liberal, op. cit., pp. 25-26. Marta Ruiz Jiménez, El liberalismo exaltado: la Confederación de comuneros españoles durante el Trienio Liberal, Ed. Fundamentos, 2007. Michel Mondejar, Alliance et conflits au sein des sociétés secrètes libérales: la confédération des chevaliers comuneros ou les limites de l'illusion démocratique durant le triennat constitutionnel 1820-1823, tesis dirigida por Gérard Dufour, profesor en la Universidad de Provenza, y sostenida en 2007.

Sobre los masones, cf. en particular (clasificación cronológica): José A. Ferrer Benimeli, Masonería española contemporánea, vol. I, 1800-1868, Madrid, Siglo XXI de España Editores, 1980, pp. 134-151. Paso por alto otras obras suyas publicadas más tarde en 1989, 1996 y 2010. Luis P. Martín, La masonería en Castilla y León, Ediciones Diputación de Salamanca, 1996. Emilio La Parra, Los Cien Mil Hijos de San Luis, op. cit., pp. 183-194.

16 Se ha adoptado la exacta grafia española. 
aborrecibles sucesos se han de achacar a los comuneros (sic) en unión con cierta clase de masones" (22 de septiembre). Unos y otros han tenido la habilidad malévola de declarar responsable de los disturbios al general Zayas "17, "valiente militar, excelente ciudadano, particularmente conocido por su apego al rey y por su odio de cuanto lleva el sello de la anarquía".

Me siento incapaz de pronunciarme acerca de un desacuerdo a propósito de la comunería y de la masonería, entre Alberto Gil Novales y Luis P. Martín autor de una obra en la que se lee que "pretender que la comunería es una hispanización de la masonería, nos parece conceder a ésta un papel que no tuvo". En efecto, según Luis P. Martín, no está demostrado que los comuneros son hijos de la masonería" 18 .

Aunque en algunas ocasiones, se resalta una homologia entre los masones, los comuneros y los carbonarios, sólo una vez en 1821 en el Journal, una noticia, que será estimada incierta, alude a la actuación de los carbonari (sic) de la península: varios diarios españoles han hablado de "un nuevo crimen de los carbonari españoles que -según se dice- han destruido ${ }^{19}$ las cárceles de Cádiz donde estaban detenidos los voluntarios realistas. Aunque consideramos esa infame secta capaz de semejante atrocidad, con todo estimamos aventurada esa noticia». En efecto, unas cartas procedentes de Sevilla y de Madrid no dicen nada al respecto (3 de junio).

\subsection{Las sociedades patrióticas}

Las primeras informaciones en el Journal se sitúan cronológicamente en el mes de enero. Luego, a partir del verano y hasta el final de diciembre, se multiplican las referencias acompañadas de una reacción de sorda o vehemente hostilidad ${ }^{20}$.

17 La extensa noticia elaborada por A. Gil Novales sorprende al lector, porque, en 1821, el general José Pascual de Zayas y Chacón era miembro de la diputación permanente de las Cortes. Pero es cierto que su credo liberal no excluye su posible hostilidad hacia los comuneros y los masones: Gil Novales, Diccionario, op. cit., t. III, 3264-3265.

18 Luis P. Martín, La masonería en Castilla y León, op. cit., p. 140. Como apuntó J.A. Ferrer Benimeli, "con la llamada insurrección de Riego y la implantación del Trienio Liberal nuevamente tuvieron lugar dos hechos importantes: la supresión de la Inquisición y la difusión de la masoneria, demostrando nuevamente la incompatibilidad de ambas instituciones" (la masoneria y la comunería): La masonería como problema politico religioso, Tlaxcala, p. 58. Acerca de la masonería existe una obra ya antigua, nada recomendable, porque se distingue por su desaforada hostilidad hacia la secta: es la de Vicente de la Fuente, Historia de las sociedades secretas antiguas y modernas en España y especialmente de la Francmasonerí, Madrid, taller de la Ed. Prensa Católica, 1933; ed. posterior en facsímil, 2012.

19 En francés: "Ont fait sauter".

20 Cf. Alberto Gil Novales, Las sociedades patrióticas (1820-1823): Las libertades de expresión y de reunión en el origen de los partidos politicos, Madrid, Tecnos, 2 vol., 1975. Si los lectores del Journal hubieran tenido acceso al Censor del 5 de agosto de 1820, seguramente hubieran compartido la opinión severísima y argumentada acerca de las sociedades patrióticas acusadas de llevar a la anarquia: "Las arengas de las reuniones no son a propósito para ilustrar y rectificar la opinión, sino más bien para extraviarla; porque no hablan a la razón, sino a las pasiones; foguean los ánimos y exaltan la imaginación; pero no enseñan ni alumbran al entendimiento", en A. Elorza, La modernización política en España (...), op. cit. p. 157. 
A principios de enero, los "clubistas" (sic) se proponen intervenir en el extranjero: "A pesar del triste estado de nuestra fuerza militar que no alcanza los 40.000 hombres, unos clubistas indignados por la inactividad en la que les mantiene el gobierno, exponen su deseo de ir, como auxiliares, a defender los constitucionales napolitanos" (7 de enero). Casi al mismo tiempo, los miembros de las sociedades patrióticas se niegan a cumplir con la orden gubernamental de cierre.

Un hecho, entre mil, basta para que los lectores del Journal tengan una idea de cierta categoria de individuos que frecuentan en Madrid las sociedades patrióticas: Don Félix Ovalle, alcalde constitucional ${ }^{21}$, había ido al café de Malta para tratar de restablecer el orden; pero, antes de salir de ese club, se dio cuenta de que le habían robado el reloj y la bolsa (13 de enero).

A finales del mes, en una "sociedad" de Madrid, una señorita exclama a propósito del cabecilla servil "El Abuelo" 22 : "Si se le detiene, no se ha de atarle, se ha de llevarle como un animal de caza, es decir ya muerto; es así como se le llevará con una seguridad máxima" (2 de febrero).

Huelga observar que, en el Journal, el enfoque de las sociedades patrióticas está total y constantemente alimentado por el odio. Antes de evocar sucintamente su actuación, vamos a escuchar, por lo menos, un testimonio revelador de la antipatía que pueden suscitar. Así, a mediados de octubre, los habitantes de Valladolid se han levantado contra "los miembros furibundos" de la sociedad patriótica local (22-23 de octubre).

A mediados de agosto, el articulista anónimo deja trasparentar el alivio y satisfacción que le inspira el éxito sólo relativo de los clubistas: "El único freno que los revolucionarios no han destruido totalmente es la religión, objeto de la labor $^{23}$ de las sociedades patrióticas" (19 de agosto). Si hemos de creer a ese articulista, los clubistas desean "la transformación de los púlpitos cristianos en tribunas populares en las que se predicaría los derechos del hombre en lugar de los pretendidos derechos de Dios". La ejecución de esa propaganda antirreligiosa y anticlerical supone la traducción y publicación de "todos los libros que la impiedad y la anarquía han engendrado en Francia en 1795".

A finales de octubre, el Journal incluye el texto de un largo artículo sacado de El Censor que, replicando a los discursos "exagerados", denuncia una secta, no nombrada:

Desorganizadora, impia y liberticida, trabaja secretamente, con un ardor incansable para precipitarnos en todos los horrores de la anarquía (...). Esa secta jacobina e inmoral anhela el robo, el saqueo, el asesinato, la ruina del trono, la destrucción del sistema actual, para sustituir la monarquía por la república de Robespierre (9 de noviembre).

La actuación de los clubs no se limita a declarar la guerra a tal o cual institución o personaje. Como se lee en el número del 15 de septiembre, los

21 Gil Novales, Diccionario, op. cit., t. II, pp. 2276-2277.

22 Manuel Hernández es un teniente coronel faccioso; será detenido en febrero de 1821; unos meses después, proclamará a Don Carlos en Aragón: Gil Novales, Diccionario, op. cit., t. II, p. 1473.

23 Se ha de entender: "Labor destructora". 
clubistas suelen ejercer una presión sobre el gobierno al sostener públicamente a algún amigo. Por ejemplo, proponen a los generales Contador ${ }^{24}$ y Rodríguez para ocupar los puestos de ministros de la Guerra y de Hacienda respectivamente.

Uno de los políticos más celebrados por los liberales exaltados es Riego, como se puede leer a finales de diciembre: cuando se anunció que Espoz y Mina renunciaba a su función de gobernador de Galicia, estalló la rabia de los clubistas de Madrid que gritaron ¡Viva Riego!» (30 de diciembre).

Las frecuentes alusiones a la Fontana de Oro en el Journal están sometidas a un enfoque constantemente denunciador, inspirado por el odio o el temor. Se buscará en vano una exposición doctrinal exhaustiva y moderada: "Sólo se celebra al pueblo como el verdadero soberano y se oyen los gritos "matar" y "degollar" a los traidores que engañan la nación y abusan de la confianza del pueblo" ( $1^{\circ}$ de septiembre). Los participantes en las reuniones son tachados, una vez, de "hombres turbulentos" y de "energúmenos" (24-25 de septiembre).

El 13 de junio, se había notado "una afluencia mayor que la acostumbrada en el club de la Fontaine-d'or (sic)". La gente se dirigía alli armada: "Nunca la osadia de los oradores revolucionarios y furibundos había alcanzado tal grado" (30 de junio). Esa clase de afirmación equivalente a denuncia se repite en agosto: "La Fontana d'Oro (sic) es el refugio de todos los ociosos y granujas de Madrid, club dirigido por individuos tales como un abogado sin ninguna causa por defender, un cura sin curato y algunos oficiales sin empleo" (16 de agosto).

La lucha de los miembros, en principio no armada, es de naturaleza oral ${ }^{25}$. De ahí la calificación degradante de los discursos tachados de "furibundos", "furiosos", "insensatos y sanguinarios". Contrastando con la gravedad de esos epitetos infamantes, una vez el articulista recorre a la ironía al evocar "esos muy hermosos discursos acerca de los placeres brindados por la fraternidad y la unión", pero, en seguida, se abandona esa perspectiva, porque, en la Fontana, "habla Caín", asesino -como es sabido- de su hermano Abel (14-15 de mayo). A finales de agosto, "apenas han salido de Madrid el rey y "los príncipes" cuando "los energúmenos han reanudado con sus vociferaciones en la Fontana de Oro" ( $1^{\circ}$ de septiembre).

Además de los discursos, en la Fontana se redactan proclamas destinadas a ser leídas públicamente o enviadas al gobierno. Unas están calificadas de "atroces e incendiarias" (19 de septiembre). Pero el articulista del Journal, resuelto a negar la popularidad del club, prefiere declarar que sólo ejerce una influencia sobre el populacho, ya que sus miembros "turbulentos" llegan a fomentar la agitación de ese populacho en realidad despreciado por ellos.

24 Diego Contador: Gil Novales, Diccionario, op. cit., t. I, p. 770.

25 Se lee en la obra de Eugenia Astur: En contraste con la elocuencia y moderación de Alcalá Galiano, había en el café de la Fontana de Oro "sujetos a quienes indebidamente se permitía hablar alli, los cuales sobrado ignorantes y faltos de comedimiento, causaban más daño que provecho a la libertad que pretendian defender (...). Y esto había de traer necesariamente ciertas rebeldias a las autoridades que, aunque sólo imputables a una minoría liberal, servían para desacreditar a todo el partido en favor de sus enemigos»: Astur (Eugenia), Riego, Oviedo, $1^{\circ}$ ed., 1933. Ed. posterior: Oviedo, Consejería de educación, cultura y deportes del Principado de Asturias, 1984, p. 266. 
Cuando se dirigen al gobierno, exigen a veces unas decisiones que sólo han de depender del rey o de los ministros. Eso ocurrió el 23 de diciembre de 1820: "Unos miembros del club de la Fontaine d'Or (sic) han sido autorizados a poner en las manos del rey una representación en la que exponen a S.M. que el ministro actual $^{26}$ es incapaz de ejercer su función y que es absolutamente necesario que S.M. nombre a otro" (7 de enero). Se afirma que más de mil individuos han firmado esa representación.

A finales de diciembre, una noticia dejaría perplejo al lector que no sabrá por qué varios diputados y magistrados, aunque deseosos de "un cambio de sistema sin prever las funestas consecuencias que ya ha fomentado", son el blanco de "los energúmenos de la Fontana de Oro que recurren a sospechas y denuncias». Dicen en voz alta que sólo esperan una circunstancia favorable para obligar a los ministros a marcharse. Puede ser que esa circunstancia corresponda a la eventual llegada de Riego a Madrid (30 de diciembre). A finales de junio, ante una enorme afluencia, se oyeron los discursos más "revolucionarios". En uno de ellos, incluso se habló de la muerte del rey (9-10 de julio). Unos meses después, uno de los oradores pide la expulsión del embajador de Francia (10-11 de septiembre).

En la misma época, se adelanta que el "idolo" (sic) es Riego: "La Fontana (sic) está llena de gente y los oradores que se han sucedido sin interrupción se esfuerzan por impedir toda inculpación de Riego".

Un poco antes, se formuló una propuesta de carácter excepcional, por ser pasmosa, irrealizable y extravagante en el final del enunciado "Un clubista de la Fontana pidió el envío de un ejército de 25.000 hombres hacia la frontera para penetrar en Francia con la bandera tricolor y proclamar allí la constitución española que sostienen ellos en unión con los liberales de París" (26 de agosto). Un poco después, se formula la misma propuesta, ligeramente enmendada: el ejército encargado de "derribar el despotismo en Francia", habrá de disponer de 10.000 hombres (10-11 de septiembre).

Aparte de esa esperanza sumamente optimista, los miembros de la Fontana de Oro se encargan de denunciar "los complots urdidos contra la libertad del pueblo en las guaridas de la tirania" (9 de septiembre).

A principios de octubre, se verifica el cierre de la sociedad, ordenado por el gobierno. Los "Comuneros de la Fontana de Oro" (sic) se trasladaron a la sede de una logia masónica, en la calle de las Tres Cruces. Una noticia procedente de Irún, el 5 de octubre, resalta la laudable repercusión del cierre del club, justificado según el Journal:

Madrid goza de una tranquilidad perfecta que se debe a las medidas enérgicas del gobierno. La verdad es que el cierre de la Fontana ha puesto un término a aquellas mociones retumbantes que, aparentemente, tienen por objetivo la felicidad pública, mientras que, en realidad, suelen fomentar exclusivamente el desorden. Pero, aunque ha sido reprimida su propensión a la agitación, no deja de ejercer una influencia funesta hasta los límites del reino (18 de octubre).

A finales de noviembre, una breve alusión lleva a suponer que las sesiones de la Fontana siguen prohibidas, porque, el día 22, "una importante reunión se

${ }^{26}$ Se pasa por alto el nombre de su ministerio. 
ha formado delante de la Fontaine d'Or" y se ha comunicado a los descamisados (sic) una noticia referida a los recientes acontecimientos en Cádiz que han alimentado el entusiasmo de la gente congregada en el club (3-4 de diciembre). Al final del año -y sin que se llegue a saber cuándo va a ocurrir el final del cierre-, la labor de la Fontana no se ha extinguido totalmente: "Aunque la Fontana de Oro no está en plena actividad, sus miembros han nombrado un presidente y un vicepresidente. En cuanto a las sesiones, se reanudarán cuando las autoridades tengan la flaqueza de permitirlo" (12 de diciembre).

\section{LOS LIBERALES}

\subsection{Su doctrina}

Como se podía prever, los conceptos básicos que se repetirán en el Journal son la libertad, la soberanía del pueblo y la Constitución ${ }^{27}$. En un manifiesto dirigido a los admirables milicianos que han realizado "prodigios", se mencionan únicamente "la patria y la constitución" (14 de diciembre). En otro largo manifiesto integralmente transcrito, los "patriotas catalanes" que rinden culto al "inmortal y leal Riego" se declaran "ardientes defensores de la libertad, del orden y de las luces". Varios historiadores del liberalismo han apuntado que, efectivamente, los liberales se dan a veces como descendientes de los ilustrados del siglo XVIII. Huelga comentar que todos los liberales, incluso los exaltados, coinciden con los absolutistas y los conservadores para rechazar la anarquía como la peor forma de desorden. A excepción de los individuos tachados de "revolucionarios" y acusados de ser republicanos, los liberales, incluso los exaltados, prometen obedecer al rey, con tal de que sea constitucional. Pero, a finales de noviembre, el Journal adelanta una noticia extraordinaria y sumamente inquietante al revelar que unos liberales madrileños se han atrevido a dirigirse al monarca de manera insultante: "No es el Cielo, sino nosotros los que le hemos proclamado rey. No se presenta como un padre cariñoso, sino como un tirano opresor de su propia familia. Ha confiado el poder político y militar a unos enemigos de la constitución" (10-11 de diciembre). Ese último enunciado habrá sorprendido o dejado perplejos a los lectores del Journal, porque una cosa es pensar que Fernando VII sintoniza con los absolutistas y quizás les sostenga secretamente y, otra cosa es creer que, ya en 1821, haya instalado a los "serviles" en el poder.

27 Obras generales que incluyen capitulos referidos al Trienio Liberal: Antonio Elorza, "La ideología moderada en el Trienio Liberal", Cuadernos Hispanoamericanos, n²88, junio de 1974 , p. 584-650. Miguel Artola, Antiguo Régimen y revolución general, Barcelona, Editorial Ariel, 1978, pp. 185-285. Josep Fontana, La crisis del Antiguo Régimen, 1808-1833, Barcelona, Editorial Critica, 1979. Alberto Gil Novales, El Trienio liberal, op. cit. Xosé R. Barreiro, Liberales y absolutistas en Galicia, Vigo, Ediciones Xerais de Galicia, 1982, pp. 133-161. María Cruz Romeo Mateo, Entre el orden y la revolución, Alicante, Instituto de Cultura "Juan Gil-Albert", 1993. Irene Castells y Antonio Moliner, Crisis del Antiguo Régimen y Revolución Liberal en España (1789-1845), Barcelona, Ariel, 2000. Jean-René Aymes, La crise de l'Ancien Régime et l'avènement du libéralisme en Espagne (1808-1833) - Essai d'histoire politico-culturelle, Paris, Ellipses, 2005. Joaquín Varela Suanzes-Carpegna, La monarquía doceañista (1810-1837), Madrid, Marcial Pons Historia, 2013, pp. 243-317. Ivana Frasquet y Encarna García (coords.), Tiempo de politica, tiempo de constitución: la monarquía hispánica entre la revolución y la reacción (1780-1840), Granada, Editorial Comares, 2018. 


\subsection{Su actuación y la represión que ejercen}

Para que funcionen las Cortes donde se elabora y completa el texto constitucional, los liberales han de participar en las elecciones, eliminando a los absolutistas. Pero son incapaces de evitar las disensiones entre los "exaltados" y los moderados entre los cuales figuran los afrancesados. Es lo que pasa, en noviembre, en Santiago de Compostela donde los "exaltados" excluyen a los moderados (26-27 de noviembre).

Preocupados por la situación alarmante de las finanzas, los liberales, a finales de julio, han conferido una gran importancia al éxito de un empréstito: "Nuestros liberales, que quieren convencer a todo el mundo de que el nuevo empréstito recién abierto por el gobierno es un excelente asunto para todos los que le den su dinero, llenan los diarios de cálculos, reflexiones y exhortaciones" (4 de agosto).

Varias veces, los liberales -diputados o no- llegan a exigir la dimisión de ministros o de jefes políticos cuyas medidas o decisiones desaprueban. Así, a finales de octubre, la "facción" (sic) de Riego ha conseguido la destitución del jefe político Moreda ${ }^{28}$ y el nombramiento, en su lugar, del intendente Queraltó29 (1213 de noviembre). En diciembre en Barcelona, los liberales no quieren recibir al jefe político Zarco del Valle, ni al capitán general "Villa-Campa»30 (14 de diciembre).

Una de las formas pacíficas de oponerse al gobierno consiste en constituir algún "club", tal como el que se forma en Madrid, a finales de noviembre, llamado "Amigos de la constitución". De él son miembros el duque de Frías ${ }^{31}$ y muchos diputados: "El objetivo de esa asamblea es rechazar los proyectos de los revolucionarios exaltados" (3-4 de diciembre).

A veces, los desfiles, cuando hay motivos para celebrar alguna buena noticia, se desarrollan pacíficamente, mientras que, en otros casos, la degeneración engendra la violencia en los discursos o en el comportamiento. Como lo expuso detalladamente José Luis Comellas, se asistió a una proliferación de signos, ritos e imágenes ${ }^{32}$.

- Pamplona, Zaragoza y Burgos

${ }^{28}$ Francisco Moreda: Gil Novales, Diccionario, op. cit., t.II., p. 2069.

${ }^{29}$ Ramón Queraltó era miembro de una comisión en Valencia: Gil Novales, Diccionario, op. cit., t.III, p. 2498.

30 Pedro Villacampa Maza de Lizana: Gil Novales, Diccionario, op. cit., t.III, pp. 3181-3184.

31 Bernardino Fernández de Velasco, XIV duque de Frías, era miembro del Consejo de Estado en 1820 y anillero en 1821: Gil Novales, Diccionario, op. cit., t.II, pp. 1086-1087.

32 "Coronas de laurel, auténticas o simuladas con hojalata pintada de verde, eran colocadas en solemne ceremonia sobre las sienes de los incruentos vencedores de la "guerra civil"; la placa constitucional era el símbolo sagrado que había que saludar respetuosamente al pasar por la plaza mayor de cada pueblo de España; el libro abierto de la Constitución era paseado por las calles en cortejos nocturnos, rodeado de hachones encendidos (...). Los colores adquirieron también significado (...). El verde, de raíz masónica, acabó consagrándose como color liberal por excelencia, lo cual obligó a los masones a recurrir al azul en su simbología particular; los comuneros adoptaron el morado, en recuerdo del pendón de Castilla (...)": J. L. Comellas, El Trienio Constitucional, op. cit., p. 35. 
A principios de febrero en Pamplona, el capitán y algunos oficiales llevan "la faja verde", signo de adhesión al liberalismo, pero muchos burgueses y todos los estudiantes se han negado a seguir la nueva moda. Unos destacamentos han cantado "trágala, cuervo" 33 al pasar delante de los estudiantes; éstos han buscado camorra con los oficiales y, cada dia, hay riñas en los cafés (10 de febrero).

También en Pamplona, a mediados de diciembre, durante dos días, la agitación callejera se atribuye a las repercusiones de las elecciones a Cortes que, lógicamente, despertaron la alegría de los ganadores y el descontento de los perdedores. Sólo se manifiestan aquéllos que, en los desfiles, tocan música, cantan el "Trágala" y gritan "iViva Riego!" Los habitantes vieron esas "ceremonias" con repulsión y temor, ante la "exaltación" de la gente que desfiló (26 de diciembre).

Se expresa, el 10 de septiembre, un vecino de Zaragoza:

La ciudad sigue en una gran agitación; en todas las ciudades de los alrededores, pobladas de liberales o, más bien, de demagogos furiosos, éstos se habian reunido en nuestra ciudad. Los organizadores contaban con la participación masiva de los habitantes, pero tuvieron que resignarse al ver que, en medio de ellos, actuó un sector del populacho más vil. Así que, cada día, nuevos grupos recorrieron las calles gritando "¡Viva Riego! ¡Abajo los calumniadores!». Al anochecer, esa horda de individuos enloquecidos esperó la noche para reanudar el griterio, es decir las canciones patrióticas, uso tolerado desde la revolución" (24-25 de septiembre).

A finales de octubre, Zaragoza ha sido de nuevo el teatro de una "agitación popular": "Desde hacía unos días, los partidarios de Riego gritaban a su favor en el teatro, el paseo y los cafés" (12-13 de noviembre) ${ }^{34}$. A finales de septiembre, en Burgos, "los revolucionarios incitan al populacho a protestar contra la puesta en libertad de algunos cómplices de Vinuesa. Según la hipótesis del articulista del Journal, se trata de la repercusión del asesinato del canónigo. Las relaciones entre los llamados "revolucionarios" y el "populacho" no resultan aclaradas en el Journal: aquí los "revolucionarios", no obligatoriamente liberales exaltados, piden el apoyo del "populacho", pero, en otros artículos, los liberales, en su doctrina o táctica, desprecian esa vil ralea, la temen y se niegan a solicitar su colaboración.

\section{- Madrid}

Las múltiples evocaciones de los disturbios en la capital no permiten aclarar la naturaleza de las opiniones de los participantes, sobre todo cuando se habla del "pueblo", y no de los liberales exaltados exclusivamente. Así, a principios de febrero, se ha producido "un levantamiento del pueblo y una agrupación de gente en torno al coche del monarca, gritando "iViva el rey constitucional!». Los guardias de corps tuvieron que intervenir (17 de febrero).

33 En francés: "Gobela, corbeau».

34 Se puede completar esa noticia con lo que escribe Emilio La Parra: "En el intento de proclamar la república en Zaragoza en 1821, figuraron como principales implicados dos franceses, uno de ellos, Cugnet de Montarlot, liberal sin tacha. Parece ser que, aunque no existen pruebas determinantes, que esa asonada -en la que no puso su mano Regato- fue organizada para desacreditar a Riego, a la sazón capitán general de Aragón (...): Emilio La Parra, Los Cien Mil Hijos de San Luis, op. cit., p. 85. 
A finales de agosto, tres días de agitación propagan el miedo a la guerra civil. Los disturbios parecen fomentados por Quiroga que arengó al pueblo. Se cantó el "Trágala" debajo de las ventanas del alojamiento de los guardias de corps como sospechosos de ser muy fieles al rey (10-11 de septiembre).

Otros tres días de agitación se producen los 18, 19 y 20 de septiembre, movimiento relacionado con la protesta por la prohibición de una procesión en la que se había expuesto el retrato de Riego. El día 18, se oyó el grito "Tragala perro la republica" (sic) (1-2 de octubre) ${ }^{35}$. Pero también tuvo lugar una manifestación hostil encabezada por unos militares que rompieron y pisotearon el retrato de Riego (6 de octubre).

El 12 de noviembre, se reúne un centenar de hombres en la "Puerta-del-Sol» (sic), gritando “¡Abajo los ministros! ¡Viva Riego!» Uno de los jefes declara que los hombres quieren "quemar con sus antorchas algunos diarios anticonstitucionales, entre otros El Universal». Se verificará el arresto de 30 hombres (26-27 de noviembre).

- Cádiz

A finales de noviembre, en Madrid, se ha formado una importante reunión delante del "club" de la Fontana de Oro y a los descamisados (sic) se ha dado lectura de las noticias procedentes de Cádiz:

La ciudad ha completado todos los preparativos de guerra para oponer una resistencia eficaz a las órdenes del rey y de los ministros y para declararse, en la primera oportunidad, libre, independiente y protectora de las demás ciudades de Andalucía que quieran establecerse según los principios de la libertad e igualdad que forman la verdadera esencia de la constitución de las cortes de 1812 (...). Los jefes revolucionarios de Cádiz acaban de enviar un ultimátum a la asamblea de las cortes, porque no quieren tener relaciones, ni con el rey, ni con sus ministros; protestan contra cuanto se ha hecho hasta ahora.

Esos rebeldes no admitirán la presencia de los funcionarios nombrados por el rey y anuncian que las principales ciudades de Andalucia están dispuestas a reunirse con los gaditanos para formar una "confederación independiente". Todas esas noticias han producido en Cádiz una sensación profunda (3-4 de diciembre).

Probablemente para atenuar el efecto de esas noticias impresionantes y siniestras, poco después en el Journal se inserta una breve alusión al "manifiesto presentado al rey en nombre de los vecinos de Cádiz". Ahora bien, los firmantes no son más que "unos intrigantes que tienen por jefes a las autoridades que esperan sacar tajadas»36. Afortunadamente, la parte sana de la población ha lamentado los desórdenes de los 15, 16 y 17 de noviembre (12 de diciembre).

En las mismas fechas, en una proclama redactada en Barcelona, se calibra el heroísmo de los gaditanos: "¡Barceloneses! Habló Cádiz; Cádiz es la hija mayor de la libertad española; todos los hijos de la gran nación han de honrarse en imitar su ejemplo. Cádiz ha hecho retumbar el idioma de la razón, de la justicia, mucho más que el lenguaje de los reyes" (14 de diciembre). Conviene resaltar el

35 Tres columnas: tamaño excepcional del artículo.

36 En francés: “Avoir part au gâteau”. 
carácter extraño y excepcional de ese párrafo totalmente favorable a los liberales gaditanos. Pero se puede explicar cómo sigue ese posicionamiento del Journal: el diario es favorable a los liberales cuando se contentan con proclamar un credo idealizado, atractivo e inofensivo, mientras que se ha de vituperar siempre a esos mismos ciudadanos cuando acuden a la violencia y promueven el desorden.

Las noticias más asombrosas y alarmantes proceden de Cádiz, ciudad que encabeza la "revolución", por ejemplo cuando se proyecta enviar unas tropas hasta el puerto de Despeñaperros para cortar las comunicaciones entre Madrid y Andalucía.

A principios de enero, el pronóstico, de amplitud espacial ilimitada, se relaciona con el recuerdo acostumbrado de la obsesiva revolución francesa, aunque, al sur del Pirineo, no se perfila un semejante desbordamiento del furor y de la barbarie: "España está ahora en el punto en el que estaba Francia en 1789, ya que los patriotas se jactan de hacer una revolución suave y pacífica; hablan de su celo a favor de la felicidad pública, y se enfadarian si se pusiera en duda su apego a la revolución y al rey. Lo más extraño es que esos patriotas españoles hallen gente dispuesta a dar crédito a sus protestas (14 de enero).

A mediados de enero, se escribe desde Madrid que se ha descubierto una correspondencia que trata de la organización de partidarios que irian hasta la frontera de Francia "enarbolando la bandera de los revolucionarios para tratar de incorporar a los vagabundos y los descontentos de los gobiernos legítimos" (16 de enero). Esas infames tentativas se atribuyen a los "clubistas".

En una carta escrita en Madrid el 29 de enero se evoca detalladamente, a lo largo de casi una columna, lo que ha pasado en Málaga: "Se ha descubierto un complot para derribar la constitución de las Cortes y sustituirlas por una forma de gobierno puramente republicano. El jefe es un tal Mendialdua Barco ${ }^{37}$, autor de una publicación periódica (...). Los conjurados hubieran puesto en libertad inmediatamente a los presidiarios que se hallan en la ciudad". Después, se halló en su domicilio, además de cartas cifradas, una proclama titulada "República española", encabezada por "El Tribuno del pueblo". Ya Mendialdua Barco había distribuido grados militares y cargos eminentes. A la cabeza de contrabandistas y ladrones, habia programado atrevidos ataques (10 de febrero).

Más de varios meses después, el enfoque general de los acontecimientos rebosa de pesimismo e inquietud. En el diario inglés el Sun, se habla de "la tendencia de los revolucionarios españoles a imitar los revolucionarios franceses en todos los dominios". El Journal confirma esa siniestra opinión: "España está ardiendo. Todos los hombres honrados están consternados; el gobierno tiembla y, en las Cortes, varios diputados protegen la facción republicana" (3-4 de diciembre). Más de una vez, los lectores del Journal habrán advertido la frecuencia obsesiva del miedo intenso a la instauración de una república, aunque ni se calibra la fuerza de esa opción, ni se describe, en plan general, la actuación efectiva de los supuestos partidarios de ese cambio radical de régimen.

Según la naturaleza y la actuación aborrecible o inquietante de los oponentes al nuevo "sistema", intervienen el gobierno, los jefes políticos, los

37 Lucas Francisco Mendialdúa Barco, desterrado en Málaga, era allí el autor de El Duende y, probablemente, de la obra teatral Riego en Morón. En 1823, será miembro de la Sociedad Patriótica Balear: Gil Novales, Diccionario, op. cit., t.II, pp. 1966-1967. 
ayuntamientos, el ejército regular y las milicias. Los adversarios son, según el caso, unos eclesiásticos o los habitantes acusados de ser, ora unos activos realistas "serviles", o unos cabecillas o los miembros de alguna partida de guerrilleros.

Huelga resaltar que, desmintiendo la propaganda de los liberales victoriosos que enfatizan el entusiasmo general de los ciudadanos, estaba lejos de extinguirse la oposición de los absolutistas, lo cual exigia que los detentores del poder tomaran unas medidas de represión más o menos severas, individuales o colectivas.

A principios de mayo, se alude en el Journal al papel ejercido por los magistrados, dado que "la justicia se ha puesto al servicio del nuevo sistema". En efecto, los magistrados son propensos a "desterrar o extrañar a los sospechosos" (7-8 de mayo).

El pueblo ejerce una presión y se hace culpable de intromisión. En efecto, los arrestos han sido exigidos por el pueblo que pidió "detenciones, exilio y destituciones" (23 de mayo).

Anteriormente a la apertura eventual de un proceso, a veces son los militares los que toman la iniciativa de intervenir, como ocurrió en Corella (Navarra): cuando la tropa vio que unos vecinos tiraban piedras contra el cartel38 de la constitución, disparó y mató a 15 campesinos ( $1^{\circ}$ de diciembre).

En marzo, unos individuos llevan ya ocho meses detenidos en Burgos por haber conspirado contra "el sistema actual del gobierno". Un defensor suyo anónimo ha publicado en Valladolid un memorial dirigido a la nación española en el que afirma que el detenido ha cometido el único crimen de haber proclamado su miedo a que se atente a la vida de Fernando VII. El acusado y un compañero suyo nunca han denunciado la Constitución. Además, no se puede admitir que el juez sea un "afrancesado", "servidor ardiente del gobierno intruso de Joseph" (25 de marzo).

En abril, en Barcelona, se produce una agitación en consecuencia del anuncio de los acontecimientos de Nápoles -no precisados-. Se ha redactado una lista de individuos calificados como "Serviles" ( sic) y se ha pedido su arresto a las autoridades locales. Esa medida "arbitraria, ilegal y anticonstitucional", primero ha sido rechazada, pero, finalmente, los magistrados la pusieron en ejecución. Y así, durante la noche del 3 de abril, "se ha violado el domicilio de los habitantes" y varios notables fueron deportados a Mallorca (20 de abril).

A principios de mayo, las noticias proceden de Cartagena donde el motín popular ha sido muy intenso: Se ha pedido la detención y el exilio de 17 personas, entre las cuales figuran el juez de primera instancia y el gobernador de la provincia; las demás son eclesiásticos y oficiales de marina. En Algeciras, se pidió el exilio de varias personas; once de ellas son los habitantes más notables de la ciudad; después de su arresto, se les ha puesto en incomunicación ${ }^{39}$ (20 de mayo).

\footnotetext{
38 En francés: “Tableau”.

39 En francés: "Mis au secret".
} 
A mediados de mayo, se examina en las Cortes el problema planteado por la decisión tomada por las autoridades de Barcelona que han enviado a la isla de Mallorca "unos individuos designados como enemigos del sistema constitucional". Unas medidas parecidas se han tomado en Oviedo, Sevilla, Málaga, y reina la incertidumbre en el gobierno. Por ejemplo, el ministro de la Guerra es más bien hostil a la deportación (26 de mayo).

En Sevilla, bajo la iniciativa de Floridablanca, se había creado una curtiduría que, ahora en el verano, no es más que "una fábrica de conspiraciones contra el sistema (sic)", fomentadas por los empleados. Por ese motivo, los liberales han mandado meter en una cárcel subterránea a todos los obreros (6-7 de agosto).

Al final de la insurrección de Salvatierra (Álava) fueron condenados a muerte los hermanos "Luxuriaga" 40 y el canónigo Ruiz de Alegría41; "Luxuriaga" fue ejecutado en medio de horripilantes torturas (19 de agosto).

Sin que se pueda generalizar, hay que apuntar la enorme diferencia, a veces, entre el delito constatado y la gravedad del castigo infligido. Así, en octubre, "Zafrilla", canónigo de Sigüenza, ha sido condenado a seis meses de detención en un convento por haber proferido en un sermón unas palabras hostiles al sistema constitucional $\left(1^{\circ}\right.$ de noviembre).

Pero, en el caso siguiente, de estar fundada la denuncia detallada, hay que admitir que los oponentes al régimen liberal estaban fuertemente preparados para fomentar una insurrección de cierta monta:

Una expedición de voluntarios de Málaga, enviada a Alhaurin ${ }^{42}$, descubrió una casa en el municipio y se apoderó de una bandera, de dos cajas de cartuchos, de un saco lleno de balas, de un sello de bronce con las palabras ¡Viva el rey!, de muchas lanzas para los jinetes, pistolas, sables y otras armas. El dueño de la casa ha sido detenido, así como varios eclesiásticos sospechados de estar al tanto del complot (24 de noviembre).

Es sabido cómo los historiadores han coincidido en resaltar, con toda la razón, que el clero, considerado como opuesto, en su mayoría, al nuevo régimen, ha sido tratado globalmente con más dureza que con benevolencia o confianza. Se lee en el Journal a principios de septiembre que "sobre todo los eclesiásticos son objeto de la severidad de los revolucionarios". Vienen a continuación los nombres de curas y abades -que paso por alto- siete condenados a muerte o encarcelados o enviados a presidios en Mallorca o África u obligados a pagar una multa. Estaban acusados de haber sido miembros de la junta apostólica de Galicia (2 de septiembre).

E1 15 de enero, "se escribe desde Murcia" que "don Luis Munoz"43, director de El Católico en Murcia entre 1820 y 1823, ha sido detenido como sospechoso de

40 Gregorio Luzurriaga: Gil Novales, Diccionario, op. cit., t. II, 1799.

41 Como lo precisa A. Gil Novales, Pedro Ruiz de Alegría fue "condenado a muerte por faccioso y se dio garrote": Diccionario, op. cit., t. III, p. 2701.

42 Hoy, Alhaurín el Grande, en la provincia de Málaga.

43 Luis Muñoz: Gil Novales, Diccionario, op. cit., t. II, p. 2120. 
ser un oponente -sin más aclaración- al sistema constitucional y un amigo del obispo de Orihuela (27 de enero).

A principios de febrero, el que será, en la literatura comprometida, la víctima más conocida, más admirable y conmovedora para los "serviles" es "el sacerdote Vinuesa que persiste en su silencio": "No quiere declarar nada a sus jueces y, en las conversaciones que mantiene con los centinelas de la guardia nacional que le vigilan, parece resignado a aceptar su suerte: Moriré -dice- en el cadalso; otros me han precedido y otros me seguirán" (13 de febrero) ${ }^{44}$. Parecerá extraño que el Journal, tal vez insuficientemente informado, no haya puesto de relieve la actuación de Vinuesa y, sobre todo, la repercusión de su ejecución en mayo de 1821. Según Alberto Gil Novales, "indudablemente, el episodio Vinuesa prepara la gran contrarrevolución de 1822"45.

Después de una breve alusión a los arrestos y destituciones que se han efectuado en Algeciras a principios de mayo, unos renglones se refieren al futuro conde de La Bisbal: "Al general O’Donnel ${ }^{46}$ se le ha dejado incomunicado en el convento de la Mercy ${ }^{47}$, con otras personas. Protestó y pidió en vano la autorización de ir a Ceuta, en África, con su familia" (23 de mayo). El brigadier Albergoti $^{48}$ ha sido llevado a Ceuta (23 de mayo).

"Salvador Trespanes" ha sido condenado en Sevilla a ser estrangulado por haber hablado con malignidad de las cortes. El pueblo pidió que fuera decapitado y que se expusiera su cabeza en la puerta de Cádiz"49 (19 de agosto).

"François Villamore"50 ha sido condenado, el 28 de septiembre, a ocho años de detención, acusado de "haber querido sustituir la república al sistema constitucional" (15-16 de octubre).

\subsection{Rafael del Riego}

En el Journal de 1821, el personaje empieza a existir, con una sola excepción, a partir de finales de agosto. Luego, figura repetidamente a lo largo de septiembre. Posteriormente, vuelve a aparecer a finales de noviembre y será evocado hasta finales de diciembre ${ }^{51}$.

44 Se lee en el Journal del 12 de mayo: "El canónigo Vinuesa ha sido condenado a muerte" (Madrid, 3 de mayo).

45 Gil Novales, Diccionario, op. cit., cap. “Asesinato de Vinuesa”, pp. 35-36.

46 Enrique José O’Donnell y Anethan: Gil Novales, Diccionario, op. cit., t. II, pp. 2197-2200.

47 Quizá se trate del convento de la Merced en Ronda.

48 Manuel María Albergoti: Gil Novales, Diccionario, op. cit., t. I, p. 87.

49 Se trata del "servil" y de casi bribón José Salvador, alias "Tres-panes" que, condenado a la pena de garrote, se benefició de la relativa generosidad de un juez que le condenó a la privación perpetua de los derechos de ciudadano y a diez años de presidio en África: Gil Novales, Diccionario, op. cit., t.III, p. 2766.

50 Francisco de Villamor: Gil Novales, Diccionario, op. cit., t. III, p. 3192.

51 Francisco Brotons, Rafael del Riego o la España libre, sin ed., 1822. G. Revsin, Riego, héroe de España, Montevideo, Ediciones Pueblos Unidos, 1946. Antonio Alcalá Galiano, "Memorias de D. Antonio Alcalá Galiano op. cit., pp. 202-204. Anónimo, Procès du général Riego, précédé d'une notice biographique, Paris, chez Ponthieu, 1823 (37 páginas). Andrés Borrego, El general Riego y los revolucionarios liberales: tentativas para restablecer el sistema constitucional durante el reinado 
En el Journal, Riego suscita, a veces, el odio, y, en general, el desprecio, por ejemplo cuando se deplora su "escaso conocimiento del mundo" (20 de septiembre). El Journal pide prestado un enunciado humorístico al periódico La Ruche d'Aquitaine para burlarse de su ingenuidad: así, cuando está lejos de Andalucía -se supone que en Madrid, Aragón o Cataluña-, "sólo se da cuenta de que no está en la Isla de León", sin anunciar una actuación programada (30 de septiembre). Sin embargo, la pobreza de su talento intelectual no excluye su extraordinaria fama. Por supuesto, puede contar con el apoyo de la Fontana de Oro (15 de septiembre).

En el verano, en los desfiles en Madrid y en varias ciudades se saluda o aplaude su retrato. A principios de agosto, sus admiradores cantan el "himno de Riego" cuya letra parecen ignorar los articulistas del Journal. Pero saben que, cuando empezó a cantarlo un batallón del $1^{\circ}$ regimiento de la Guardia Real, los responsables de dicho cuerpo impusieron un canto distinto (15 de agosto).

Durante el otoño, la popularidad de Riego no parece declinar, como lo ilustra la acogida entusiasta que le reservan los habitantes de Lérida. En el camino hacia Tarragona, los aplausos acompañaron el grito probablemente portador de una divertida exageración “¡Viva el Emperador Riego!” Pero el comentarista en el Journal habla en serio cuando añade: "Se porta como si fuera el soberano de España". En varios lugares, pasó revista a todas las tropas y les dirigió discursos (26-27 de noviembre). Sus partidarios hacen de él el propagador de las ideas de libertad y de igualdad, y se advierte que, excepcionalmente, ese enunciado no está acompañado, en el Journal, por ningún comentario negativo.

Habia presentado, varios meses antes, un carácter también excepcional una pequeña noticia, nada fundamental, pero favorable a Riego cuando se anunció que "el general acaba de renunciar a la pensión de 4.000 piastras que le habían atribuido las Cortes" (15 de septiembre). A principios de diciembre, después de las elecciones en las que triunfaron los liberales, se organizaron desfiles durante los cuales estuvieron asociados la música y los gritos “¡Viva Riego!" (26 de diciembre).

En varias ocasiones, sin que sus partidarios soñaran con su ascensión como presidente del gobierno, por lo menos hubieran celebrado su nombramiento como jefe político, por ejemplo, en Barcelona a principios de enero de 1822, sustituyendo al general Villacampa ${ }^{52}$ (21 de diciembre).

de Fernando VII, Madrid, Librería de Don Antonio San Martín, 1886. Astur (Eugenia), Riego, Oviedo, $1^{\circ}$ ed., 1933. Ed. posterior: Oviedo, Consejería de educación, cultura y deportes del Principado de Asturias, 1984. A. Gil Novales Rafael del Riego: La revolución de 1820, dia a dia. Cartas, escritos y discursos, Madrid, Tecnos, 1976; Del mismo autor, El Trienio liberal, op. cit., pp. 41-43. Lucienne Domergue, "Don Rafael del Riego ahorcado", en Ejército, pueblo y Constitución. Siglos XIX y XX - Homenaje al General Rafael del Riego, revista Trienio, Madrid, 1988, pp. 115127. Mercedes Gutiérrez Nogales, Rafael del Riego: datos biográficos, romancero y documentos, ed. M. Gutiérrez, 1988. Riego en el Diccionario Biográfico de Parlamentarios Españoles, vol.2 (18201823), Cortes Generales, 2012, edición en DVD. Carmen de Burgos, Gloriosa vida y desdichada muerte de Riego, Sevilla, Centro de Estudios andaluces / Editorial Renacimiento, 2013. Victor Sánchez Martín, Rafael del Riego, simbolo de la Revolución Liberal, tesis de doctorado, Universidad de Alicante, 2016.

52 Pedro Villacampa Maza de Lizana: Gil Novales, Diccionario, op. cit., t.III, pp. 3181-3184. 
Menos mencionado, en el Journal, que el "himno de Riego" ha sido lo que se puede llamar "la moda Riego". En efecto, con sorpresa para el lector, éste halla lo siguiente en el número del 25 de agosto: "Los hombres de origen noble 53 no pueden mostrarse en un club o en el paseo sin llevar un sombrero a estilo del de Riego y unas botas a estilo de las de Ypsilanti"54 (25 de agosto).

Las noticias referidas a los desplazamientos, discursos y tomas de posición de Riego son tan pobres y fragmentadas, con largos silencios y citas de simples rumores, que los lectores del Journal no pueden, ni seguir su carrera, ni -como vimos- aprehender su naturaleza y manera de ser.

A finales de agosto, está calificado, de forma neutral, de "corifeo de la sociedad patriótica de Zaragoza" en compañía de Espoz y Mina, "corifeo" de la misma sociedad en Galicia (25 de agosto).

El Journal de septiembre pide prestado al periódico La Ruche d'Aquitaine un artículo interesante, pero que dificulta la búsqueda de una confirmación: "Se escribe en Oleron ${ }^{55}$, el 5 de septiembre, que hubo un gran movimiento en Zaragoza, los 30 y 31 de agosto, para proclamar la república. Los facciosos han fracasado gracias a la firmeza del jefe político "La Morena"56. Riego, ayudado por algunos oficiales franceses y por el ex redactor "L'homme gris" 57 , encabezaba el movimiento. No le ha apoyado la tropa y se le está persiguiendo" (15 de septiembre).

En el Journal se acumulan ahora las noticias controvertibles y dificiles de articular. A principios de septiembre, se anunció que el jefe político de Zaragoza ha ordenado el arresto de Riego y su traslado a Lérida (15 de septiembre). Intentó no ir allí, pero se le detuvo y "el autor de la insurrección de Cádiz" tuvo que regresar a Zaragoza (20 de septiembre). En la capital de Aragón, su vuelta provocó "un enorme tumulto" (22 de septiembre).

En una "Correspondencia particular" se mencionan dos rumores pasmosos. Según el primero, Riego se dispone a encabezar una república en España. Según el otro, aún más asombroso, por no decir estrafalario, tiene previsto entrar en Francia para proclamar allí la Constitución española (19 de septiembre). Pero ese rumor no tardará en ser desmentido. Se advierte que el plan de Riego no espanta al articulista del Journal, por estar convencido de que los liberales franceses se opondrían a una intrusión de sus eventuales amigos del sur del Pirineo: "Lo cierto es que, si esa locura penetrara en la cabeza de los liberalès (sic) de España, éstos hallarian en Francia unos fieles ${ }^{58}$ resueltos a obligarles a arrepentirse de sus proyectos".

En la misma época, se completa y diversifica la información:

"Riego ha sido engañado por unos aventureros extranjeros que querian invitarle a penetrar en los departamentos meridionales de Francia. Esos

\footnotetext{
53 En francés: "Bien nés".

54 Alejandro Ypsilanti (1792-1828) era un militar griego y un héroe nacional.

55 En realidad, Oloron, cerca de la frontera pirenaica.

56 Grafia dudosa.

57 Ese "hombre gris" es Cugnet de Montarlot de que quien se hablará más adelante.

58 Es decir: súbditos fieles al rey de Francia.
} 
aventureros se declaraban los apoderados de algunos jefes de partidos en París. A Riego se le atribuye como consejero al francés Cugnet de Montarlot ${ }^{59}$, escritor que residia en España desde hacía algún tiempo" (17-18 de septiembre). Ese militar, conspirador durante la Restauración, republicano, masón, era un comisionado para intervenir en España y hacer triunfar alli la libertad y los derechos del hombre. Se instaló en Zaragoza durante el verano de 1821 y se declaraba nada menos que "general en jefe de los ejércitos revolucionarios" (19 de septiembre). Curiosamente, en un artículo titulado con ironía "Tontos en revolución", se alude al "soberano Cugnet $1^{\circ}$ " que acaba de ascender al general La Fayette al grado de teniente general de las guardias nacionales, y está muy conocido como un "super tonto" (19 de septiembre).

En el Journal del 30 de septiembre está transcrito integralmente un artículo de La Ruche d'Aquitaine: calificados de héroes por antítesis irónica, los señores Riego y Cugnet de Montarlot han tenido que renunciar a poner en práctica su complot: "La facción franco-española -se dice- había previsto entrar por sorpresa en Perpiñán". Riego, a la cabeza de un puñado de bandoleros y de desterrados, advirtiendo que se tocaba a rebato en todos los pequeños pueblos, tomó el partido de replegarse con su tropa hasta el cuerpo del ejército "mandado en persona por el generalísimo, presidente del imperio, el gran maestre de la orden del Sol, el gran Cugnet de Montarlot" (30 de septiembre). Huelga precisar que todos esos títulos exagerados han sido inventados para ridiculizar al ominoso personaje concernido.

En el número del 27 de septiembre se había transcrito en el Journal un párrafo del periódico La Foudre, de su número $28^{60}$. En él se aludía a un metafórico rayo, o sea "foudre" en francés, que apunta a los liberales: "Montarlot $y$ Riego, parodia de Pícaros y Diego, tal es el título de un drama patriótico que iba a ser representado (...). Conspiración, asesinatos, marchas de tropas, rebato, toque de alarma, cañones, en definitiva, todo cuanto puede inspirar el terror y la piedad se halla reunido en esa obra" (27 de septiembre). Curiosamente, no se especifica si esa obra estaba destinada a ser representada en París o en España. Pero sí se precisa que el abandono del proyecto correspondió con el encarcelamiento de uno de los dos protagonistas, que, en aquellas fechas, no podía ser sino Cugnet de Montarlot.

Hay que remontarse mucho en el tiempo, hasta mediados de enero, para oir hablar de una obra teatral que se ofreció al público madrileño, con el título Riego en Sevilla. En el desenlace -y alli el breve comentario incluye un toque de ironía maligna-, "el general declara que, a partir de ahora, todos los crios han de chupar la Constitución española con la leche de sus nodrizas" (20 de enero).

En nuestra breve despedida vamos a aludir a una carta escrita en Bayona y dirigida al Journal que publicará un extracto en el número del penúltimo día de 1821: en conformidad con lo que ha sido el enfoque constante a lo largo del año, a Riego sólo le rinden culto unos individuos nada recomendables, propensos a la

59 Cf. el artículo de Laurent Nagy, "Un conspirateur républicain-démocrate sous la Restauration: Claude François Cugnet de Montarlot", Annales historiques de la Révolution française, $\mathrm{n}^{\circ} 370$, octubre - diciembre de 2012.

60 Título completo: Journal de la Littérature, des Spectacles et des Arts. 
violencia y amigos del desorden: "El nombre de ese señor viene a ser definitivamente el santo y seña de los furiosos" (30 de diciembre).

Ahora, un extenso post scríptum: A pesar del papel notable desempeñado por las logias masónicas a lo largo de la primera mitad del siglo XIX (Guerra de la Independencia y Sexenio absolutista), mientras que el Journal dedica unos espacios a los Comuneros, sigue ignorando la actuación de los masones o ha adoptado el silencio al respecto. Y eso que habia la posibilidad de asociar a Riego con su pertenencia a la masonería, como lo apuntó José A. Ferrer Benimeli refiriéndose precisamente al año que nos interesa:

"En 1821, siguiendo la trayectoria de distorsión de los hechos, será el entonces popular general Riego el que sustituya al conde de Montijo como Gran Maestre del Grande Oriente Nacional, cargo que -según las historias al usodesempeñaria hasta su muerte en $1823 " 61$.

\subsection{Francisco Espoz y Mina}

Se nota un llamativo contraste entre el extenso espacio ocupado por el político Riego y el escaso interés suscitado por el militar Espoz y Mina, a menudo designado, a secas, como Mina62. Éste apenas supera al "Empecinado" que "ha pasado a ser sospechoso para los patriotas" (28-29 de mayo). A propósito de Espoz y Mina, se extiende un largo silencio a partir de la primavera hasta diciembre.

El primer comentario acerca de su conducta es francamente desfavorable, porque se insiste en su crueldad: "Se dice que a Espoz y Mina le ha parecido más fácil mandar ejecutar a las personas detenidas en Galicia que desterrarlas a las islas Canarias. Así imita al revolucionario Barrere ${ }^{63}$, cómplice de Robespierre; ambos decían que "no reaparecian los muertos" (28-29 de mayo).

A finales de noviembre, Espoz y Mina da, efectivamente, la impresión, de portarse como un liberal exaltado, casi como un revolucionario: "La Coruña mandada por el famoso Mina apodado el Republicano aprueba la conducta de Cádiz opuesta al gobierno" (27 de noviembre).

61 José A. Ferrer Benimeli, Masonería española contemporánea, op. cit., p;143.

62 Citas bibliográficas, con exclusión de las obras que se refieren a la actuación del cabecilla durante la Guerra de la Independencia (clasificación cronológica): José de Grijalva, D. Francisco Espoz y Mina, o sea, Reseña histórica de la vida militar y politica de este héroe español, Barcelona, Imprenta de D.J.M. de Grau, 1840. Condesa de Espoz y Mina, Memorias de la Excma Sra. Condesa de Espoz y Mina - Segunda parte: En honor de Mina - Memorias intimas, 1820 a 1836 , Madrid, Hijos de M.G. Hernández, 1910 - Ed. posterior: Madrid, Sociedad Estatal de Conmemoraciones Culturales, 2006. Miguel Artola Gallego, "Edición y estudio preliminar" de Espoz y Mina (Francisco), Memorias del general Don Francisco Espoz y Mina, Madrid, ed. Rivadeneyra, 1851-1852, 5 tomos - Ed. posterior: Madrid, B.A.E., tomos CXLVI y CXLVII, 1962, pp. IX-XLIII. José María Iribarren, Espoz y Mina el liberal, Madrid, Aguilar, 1967 - Obra fundamental: cf. en particular los cap. 48, 49 y 50, pp. 321-341. Irene Castells, La utopía insurreccional del liberalismo, op. cit.,. Ramón Arnabat, Visca el rei i la religió! La primera guerra civil de la Catalunya contemporània, Lleida, Pagès editor, 2006, pp. 303-309.

63 Bertrand Barère, alias Barère de Vieuzac (1755-1841), orador famoso, primero moderado, después apoyó a Robespierre. 
Como ocurre de vez en cuando en el Journal, se llega a confundir "noticia" y "rumor". Es lo que se constata en la información procedente de Irún, el 7 de diciembre: "Las tropas de Mina, de Riego y otras en Andalucía van a invadir Madrid" (19 de diciembre). Se repite el rumor según el cual "las tropas y las milicias se reúnen en un cuerpo de ejército encabezado por el comandante militar Espoz Mina (sic) que -se añade- puede ser que se haya puesto en marcha hacia Madrid".

Sólo a mediados de diciembre, se atenúa la hostilidad hacia el personaje mediante una noticia tranquilizadora que tal vez es una réplica a un rumor: "Espoz y Mina sigue sin comunicación con los rebeldes de Andalucía" (26 de diciembre).

Sin embargo, se observa una pérdida de prestigio y de relaciones amistosas: Mina está ya "desestimado por los patriotas puros" y ha sido sustituido como gobernador de Galicia por "Ramond Lopès"64. Pero, de forma contradictoria, se alude a su extraordinaria popularidad en La Coruña donde está considerado como "el caudillo de la libertad" (30 de diciembre).

Se puede completar la información acudiendo a José María Iribarren a propósito de Espoz y Mina, comandante general de Galicia: está acusado de republicano y de aspirar a la dictadura. Suscribe un manifiesto contra el gobierno y el rey le quita el mando. Pero viene la confirmación de lo que se mencionó acerca de la popularidad de Espoz y Mina: el pueblo coruñés se opuso a la orden real y consiguió que fuera repuesto. E1 ministro le obligó a salir de Galicia65.

\section{LOS REALISTAS Y LOS “SERVILES"}

Es sabido cómo el triunfo de la "revolución" encabezada por Riego desencadenó el enfrentamiento entre los partidarios del "nuevo sistema" y los oponentes. Aquéllos se llaman o se llamarán "liberales", "constitucionalistas", y éstos, "realistas", o "contrarrevolucionarios", o "serviles"66.

\subsection{Las bases doctrinales}

Una de ellas es la fidelidad fervorosa, constante, sin fallo ni vacilación, a la monarquía encarnada por Fernando VII y los infantes, en particular Don Carlos. Se trata, en concreto, de conseguir el restablecimiento de todos los derechos de que gozaba Fernando VII después de la Guerra de la Independencia.

64 Es probablemente el brigadier Ramón Lope y Pérez, director subinspector de Ingenieros: Gil Novales, Diccionario, op. cit., t.II, p. 1726.

65 Iribarren, Espoz y Mina el liberal, op. cit., pp. 327-335.

66 Jaume Torras Elías, Liberalismo y rebeldia campesina, 1820-1823, Barcelona, Ariel, 1976. Xosé R. Barreiro, Liberales y absolutistas en Galicia, op. cit., pp. 105-132. Ramón del Río Aldaz, Orígenes de la guerra carlista en Navarra (1820-1824), Pamplona, Gobierno de Navarra, 1987. Encarnación García Monerris, La crisis del antiguo régimen y los absolutismos, Madrid, Sintesis, 1994. Alexandra Wilhemsen, La formación del pensamiento político del carlismo (1810-1875), Madrid, Actas, 1995. Pedro Rújula López, Contrarrevolución. Realismo y Carlismo en Aragón y el Maestrazgo, 1820-1840, Zaragoza, Prensas Universitarias de Zaragoza, 1998. Ramon Arnabat Mata, La revolució de 1820 i el Trienni Liberal a Catalunya, Vic, Eumo Editorial / Universitat de Vic, 2001. Del mismo autor, Visca el rei i la religió!, op. cit. 
En contraste con la unanimidad para poner un término a la revolución y al "nuevo sistema", se perfila una divergencia, ni radical ni fundamental, no anunciadora de una ruptura: en efecto, unos realistas desean el restablecimiento del régimen que abarcó el Sexenio (1814-1820), mientras que otros, minoritarios, según el Journal, están dispuestos a aceptar ciertas reformas razonables y desean (ilusionadamente) una reconciliación con los liberales moderados, lo que aseguraría la paz interior.

En el Journal, el credo de los realistas se plasma en los gritos que lanzan durante los desfiles y las procesiones organizados por ellos. En esos gritos suele figurar a menudo la religión. En efecto, sabemos -lo veremos en otro capítulocómo la mayoría del clero, desde los prelados hasta los párrocos y los monjes, se declara víctima de los liberales calificados como anticlericales, masones o ateos.

En la cita siguiente, se notará cómo las milicias son las que están encargadas de neutralizar a los oponentes: "Una compañia de cincuenta hombres a caballo, fuertemente armados, atravesó el pueblo de Montemajor (Montemayor), cerca de Córdoba, en los últimos días de julio, gritando ¡viva el rey! ¡viva la religión! Las autoridades constitucionales han enviado una compañia de milicias para perseguirles" (20-21 de agosto).

\subsection{La lucha organizada}

A principios de junio, redacta una proclama el cura de Villoviado (provincia de Burgos), lugar de nacimiento del admirable Merino, "terrible cabecilla que está a la cabeza de un cuartel general" y que deplora el triunfo de una "facción", sin que esté precisado si se trata de una "facción" liberal o revolucionaria: "Son hombres sin talento, sin medios, sin ninguna clase de conocimiento y sin otro móvil que una ambición desenfrenada" (13 de junio). Para el cura claramente absolutista, uno de los acontecimientos más funestos es la nueva instauración de las Cortes.

El autor anónimo de una "carta particular" escrita en Madrid el 4 de septiembre denuncia, con prolijidad y manifiesta exageración, los proyectos, abusos y crimenes de los que han usurpado el poder: la mitad de ellos son aviesos y, la otra mitad, extravagantes. Su objetivo es "el aniquilamiento del trono y el establecimiento de la república con todas sus consecuencias". El título de "la república cristiana" -sorprendente adjetivación- no se ha fijado todavia: podrá ser "república ibérica o iberiana (sic)" o "república española". Esos infames individuos han multiplicado "las matanzas jurídicas o populares de Vinuesa y otros", así como "las mociones atroces o incendiarias de la Fontana de Oro". La principal víctima de su malignidad ha sido el monarca presentado por los adversarios como "enemigo del pueblo": procura rodearse de hombres depravados e inmorales, y está siempre dispuesto a quebrantar sus juramentos (19 de septiembre).

En el Journal del 9 de noviembre, se transcribe un largo artículo de $E l$ Censor en el que se denuncia una "secta" que "quiere precipitar a los españoles en todos los horrores de la anarquía". El despotismo de un populacho "desenfrenado, bárbaro, cruel y sanguinario" acompañará "la disolución social” (9 de noviembre).

Con tal de que los militantes realistas no hayan tomado la decisión de no participar en las elecciones, votarán a favor de los antiliberales, es decir "a favor 
de la familia reinante y de las instituciones que la familia reinante ha dejado a España" antes de la revolución de 1820, como lo supondrán los lectores del Journal. Tales como las enfoca el diario, las elecciones parecen desvirtuadas por irregularidades, violencias y amenazas cuyas víctimas son exclusivamente los intachables adversarios del nuevo régimen: "Muchos serviles (sic), es decir personas honradas, se han quedado en casa sin valerse de sus derechos. Los que se han atrevido a votar han sido repelidos a estacazos" (22-23 de octubre).

Escrita en Bayona el 18 de diciembre, una carta proporciona una excelente noticia para los realistas y -se supone- para los lectores del Journal: "Las provincias de Álava, Guipúzcoa y Navarra han elegido como diputados a unos hombres religiosos y monárquicos, enemigos declarados de la Constitución de Cádiz" (24-25 de diciembre). Otra alentadora noticia deja pensar que, en Zaragoza, no triunfaron los liberales, ya que "el pueblo ha derribado los carteles 67 y las piedras de la Constitución, pero las tropas tomaron las armas para defender esos "monumentos de la rebeldía ( $\mathrm{sic}$ ) de Riego". Completando el anuncio de que los realistas habian triunfado -como vimos- en Álava, Guipúzcoa y Vizcaya, figura otra noticia que, unos días después, propone la explicación de la victoria de los liberales en la capital de Vizcaya: "Las cartas de Bayona anuncian que Bilbao ha sido el teatro de desórdenes con motivo del nombramiento de las autoridades municipales. La ciudad estaba dividida en cuatro partidos que tenían cada uno sus candidatos. Habiendo conseguido la mayoría el de los liberales, el pueblo dejó estallar su descontento y se agrupó en la plaza central" (29 de diciembre).

Para conseguir el restablecimiento del régimen político ideal, en una primera etapa hay que eliminar el gobierno. En julio, en el artículo dedicado esencialmente a los liberales y a los comuneros, un pequeño espacio está reservado a los "realistas" designados por los liberales con un nombre destinado a fomentar hacia ellos el odio y el desdén; en efecto, los liberales les califican con malignidad de "serviles", vocablo de por sí despectivo (19 de julio).

Apenas se menciona sucintamente y sólo una vez la "junta apostólica de Galicia”. Como se verá adelante se diría que la resistencia armada más activa y extendida está encabezada por el cura Merino. En los inicios de 1821, un corresponsal madrileño del Journal anuncia que, en Andalucía y en otras provincias, la insurrección es fomentada por los partidarios del antiguo régimen: "Se dice que el jefe politico de Granada ha enviado una lista de varios oficiales de la milicia que han desertado con los soldados de su compañía. Los hombres que encabezan los defensores de la fe (sic) son, en su mayoría, campesinos o artesanos que anhelan hacerse famosos como los Mina y otros cabecillas"68 (2930 de enero). En los montes cerca de León, se ha constituido un "comité secreto anticonstitucional que la policia no llega a descubrir" (12 - 13 de marzo).

En abril, estalla una potente insurrección en Álava que produce una enorme sensación en la población, porque se alude a unos mil hombres que han provocado el repliegue de las tropas enviadas allí para eliminarles.

A mediados de junio, se da a conocer en el Journal una extensa y detallada noticia, aunque parcialmente incierta, redactada en Madrid, el 29 de mayo:

67 Empleo extraño de "tableaux" en francés.

68 En francés: "Chefs de guérillas". 
Corrió el rumor, en la noche, de que se había detenido al prior del convento de dominicos de Atocha, convento situado al final del Retiro y donde hay una capilla a la que va a menudo el rey. Según se dice, se acusa al prior de haber elaborado un proyecto de contrarrevolución. Alistaba y retribuía regularmente sus partidarios. También se ha hallado en el convento cierta cantidad de fusiles y otras armas, así como municiones y muchísimos papeles sospechosos. Se asegura que se ha llevado al prior a la cárcel donde está Vinuesa (13 de junio).

"Jaime Alfonso", en realidad Jaime Alfonso Martinez, alias "El Barbudo", ha anunciado, después del asesinato de unos amigos intimos, que mandará ejecutar a todos los vecinos de una aldea -sin precisar cuál es- si caen en sus manos: "A partir de aquel entonces, nadie se atreve a salir al campo, y la aldea está rodeada de barricadas, prueba de que Jaime Alfonso inspira el terror" (13 de junio)69. Unos dias después, en una breve noticia, Jaime Alfonso se llama ahora, a secas, "Jaime": "Su columna, en Valencia, ha entrado en la provincia de Murcia. Ha tenido una recepción perfecta y ha empezado a reclutar con mucho éxito" (17 de junio).

Otro cabecilla, conocido por su apodo "Martilo" o, seguramente, "Martillo", amenaza la capital a finales de agosto (8 de septiembre). Si se trata de "Martillo", su apellido es Juan Larios de Medrano, "militar y poeta bilingüe (...), miembro de la Academia de Buenas Letras de Barcelona”, según A. Gil Novales. Su muerte, en 1823, quizás se haya de atribuir a la epidemia de fiebre amarilla ${ }^{70}$.

En el verano, Pedro Zaldivar ${ }^{71}$ que levantó una partida en 1821 , calificado de "segundo Merino en Andalucía", actúa "desde Algeciras hasta Jerez" (4 de julio). Trata de reunirse con Merino. Ha reclutado descontentos (20-21 de agosto). Zaldivar y Merino preocupan mucho a los jefes politicos y a los milicianos. Unos y otros tratan de conseguir la colaboración de otros cabecillas ${ }^{72}$ con el objetivo de ocupar el litoral y -enunciado insuficientemente aclarado- de "encerrar a los constitucionales en un gran círculo"73. A finales de agosto, las autoridades doblan la cantidad de dinero que se entregará a la persona que facilite el arresto de Zaldivar. Éste se ha mostrado en Obejo (provincia de Córdoba), acompañado por trece jinetes, pero esta tropa se hace más numerosa cada vez que el cabecilla está amenazado (2-3 de septiembre).

En una carta escrita en Madrid el 4 de agosto, se había anunciado que, en los alrededores de la ciudad catalana de Manresa, el monje mínimo "Bonaventure Fulset ${ }^{74}$ había reunido unos 250 descontentos, campesinos en su mayoría, con la

69 Jaime José Cayetano Alfonso, alias “El Barbudo” (1783-1824), pastor y, luego, bandolero, luchó contra los franceses durante la Guerra de la Independencia. Durante el Trienio, se declaró enemigo de los liberales y colaboró con los "Cien Mil Hijos de San Luis".

70 Gil Novales, Diccionario, op. cit., t. II, p. 1653.

71 Gil Novales, Diccionario, op. cit., t. III, p. 3253.

72 Sólo una vez se menciona al "Abuelo" que, según lo que se afirma, conspira, perseguido por los guardias nacionales de Madrid (2 de febrero). Se trata de Hernández Manuel, alias "El Abuelo", detenido en febrero de 1821 por el alcalde y la Milicia Nacional de Helechosa (provincia de Badajoz): Gil Novales, Diccionario, op. cit., t. II, p. 1473.

73 Quizá se trate de las provinciales centrales: ambas Castillas y León.

74 Está ausente en el Diccionario, op. cit., de A. Gil Novales. 
intención, según se decía, de proclamar la abolición de la Constitución". Pero un coronel dispersó el grupo. En un carro se halló el vestido propio de los eclesiásticos que el monje habia dejado para adoptar el uniforme militar. En el Diario Constitucional de Barcelona, se completa la información con datos originales que no carecen de interés: los monjes dominicos de Manresa, cuyo convento habia sido cerrado recientemente, habian proporcionado a Fulset la posibilidad de reclutar su tropa en la población rural a la que "los dominicos habían ofrecido el espectáculo de su procesión acompañada de la venta de crucifijos y de rosarios, así como de la concesión de indulgencias" (4 de agosto).

A finales de noviembre, en Ciudad Real, "unos grupos numerosos recorren la ciudad gritando ¡Mueran la república y los republicanos!” Tales como están evocados en el Journal, no inspiran el odio, el temor o el desprecio, porque no se les califica de miembros del populacho y porque se han pronunciado a favor de la familia reinante (12 de diciembre).

Como se ha apuntado en el examen de los abusos cometidos por las autoridades liberales en menoscabo de los realistas, en Barcelona a principios de abril, entre los personajes notables figuran "el general barón de Eroles, el general "Farfield"75, el obispo de Barcelona, el primer vicario-general, varios canónigos, el superior de los capuchinos, los generales Fournas76, "Campdell"77 y "Roxa"78. También se detuvo a los obispos de Tarragona, Tortosa y Vich" (20 de abril).

En julio, se encarcela al canónigo Castro, "uno de los 69 diputados llamados Persas". Colabora con Mataflorida y con Antonio Gómez Calderón, "jurisconsulto del Consejo de Indias"79 (22 de julio).

Después del arresto de "Blas Ostolaza", más exactamente, Blas Gregorio de Ostolaza, varias personas protestaron, estimando que "basta no estar satisfecho de la Constitución para ser echado en un calabozo". Ostolaza fue transferido como detenido, en los inicios de la revolución de 1820, de una cárcel de Sevilla a la Cartuja donde "intrigó contra la Constitución"80. Varios años antes, en un artículo en el Journal se le había mencionado como encerrado "en las cárceles que eran las de la inquisición y que ahora son los calabozos utilizados por la inquisición revolucionaria" (27 de enero). Circuló el rumor de que le envenenaron durante su detención, pero aquello no era más que un rumor, dado que murió sólo en 1835.

75 Pedro Farsfield Water, I conde de Sarsfield, "fue llevado por servil al lazareto de Mallorca y, de alli, a Ibiza: Gil Novales, Diccionario, op. cit., t. III, pp. 2843-2844.

76 Blas de Fournas de Labrosse, francés nacido en Narbona, había luchado en su patria contra la Revolución y, luego, en España, contra los invasores napoleónicos. A principios de 1820, se opuso al levantamiento liberal. Posteriormente, se retiró a Francia: Gil Novales, Diccionario, op. cit., t. I, pp. 1142-1143.

77 El brigadier Patricio Campbell fue expulsado de Barcelona por servil en marzo de 1820: Gil Novales, Diccionario, op. cit., t. I, p. 561.

78 Un desconocido, tal vez Roza.

79 En junio de 1823, el canónigo firmará el manifiesto "La Regencia del Reino durante la cautividad del rey nuestro señor (...): Gil Novales, Diccionario, op. cit., t. II, pp. 1332-1333.

80 Gil Novales, Diccionario, op. cit., t. II, pp. 2271-2273. 


\subsection{Jerónimo Merino}

Las noticias que le conciernen en el Journal de 1821 sólo cubren el periodo que transcurre desde el principio de abril hasta agosto. Huelga comentar que se beneficia en el diario de una gran popularidad, porque "el cura Merino, valiente y obstinado, ha mostrado una admirable constancia" (19 de julio).

Señal de que el responsable del Journal se honra de dar a conocer, lo más a fondo posible, al personaje, transcribe -algo excepcional- la totalidad de la extensa proclama dirigida por él a los castellanos, pronunciada, el $1^{\circ}$ de abril, en el cuartel general de "Alienza", en realidad Atienza (provincia de Guadalajara) (4 de julio).

La finalidad de ese discurso es llamar a la lucha contra los adversarios, no abandonarse a la pasividad y reemprender "los esfuerzos heroicos que desplegaron los españoles contra las tropas de Napoleón".

El lema de Merino es "religión, rey y representación nacional": extraño concepto el último, porque, a pesar de la ausencia del término "Cortes", es más propio de los liberales. Así que a Merino no se le puede calificar de absolutista radical. Por cierto, exige el restablecimiento de los derechos del rey, pero no habla de los derechos ilimitados que convertirian a Fernando VII en un déspota o un tirano.

Los objetivos atractivos y alcanzables que se han fijado los miembros de las "falanges "(sic) de Merino son la defensa de la religión, el apoyo sólido prestado al trono, el terror para los enemigos y el bulevar (sic) abierto para la libertad civil, el respeto de los privilegios - sin especificar- y los derechos de la nación: mi observación repite la anterior, porque, aparte de los "privilegios" sin especificar, "libertad civil" y "derechos de la nación" en lugar de "derechos (sagrados) del monarca" son conceptos que pertenecen a la ideología liberal. Pero es cierto que, dirigiéndose a los castellanos indistintamente, Merino habrá soñado con ser acogido favorablemente por los compatriotas todavía indecisos.

Los españoles son "el juguete de una secta de materialistas" cuyas víctimas más eminentes son el rey y, en segundo lugar, su familia apenas mencionada en la proclama. El monarca está privado de libertad, reducido a una forma de esclavitud y sometido a una cuadrilla ${ }^{81}$ dominante, ya que se ha suprimido la "guardia real" (o guardia de corps). El monarca es insultado y -afirmación nada fidedigna- se le tiran piedras.

La situación del país es "triste" y "horrible": desaparece la seguridad individual, se insulta la paternidad y las mujeres están expuestas a la violación. La situación personal de Merino sería lastimosa o trágica si triunfaran los contrarios, porque vive bajo la amenaza de estar reducido a la esclavitud o degollado en su domicilio.

Todo lo que precede está sacado de la proclama, pero no la información siguiente que se refiere a la ideología del cura: su lucha contra los defensores del aborrecido nuevo régimen incluye, al mismo tiempo, a los adversarios y a los signos públicos de su credo. Por ejemplo, a principios de junio, Merino, confiriendo una clara significación a sus propias convicciones, "sigue derribando y borrando todos los emblemas o inscripciones constitucionales" (18-19 de junio).

81 "Horde" en francés y, en castellano, banda de casi brigantes. 
A mediados de abril, sus operaciones, no todas armadas y mortiferas, van con viento en popa, ya que "las guerrillas de Merino se han apoderado cerca de Lerma (provincia de Burgos) del coche correo procedente de París" (17 de abril).

Como sucede a menudo, la popularidad de Merino se acompaña del odio que apunta a sus adversarios: "Cuando la guarnición del cura de Villoviado82 evacuó Salvatierra ${ }^{83}$ a principios de mayo, los vecinos -como se lee en una carta procedente de alli- han tenido que aguantar un pequeño saqueo cuando las tropas constitucionales entraron en el pueblo" (12 de mayo).

También a principios de mayo, se afirma que la tropa de Merino se incrementa, alcanzando la cifra de 500 hombres, compuesta en su mayoría de campesinos y de eclesiásticos. En un enfrentamiento con la tropa de Mendizábal han muerto 50 hombres de Merino. El cura sólo dispone de una caballería que procura reforzar apoderándose de los caballos pertenecientes al ejército y a la guardia nacional (7-8 de mayo).

A finales de mayo, más de la mitad de una columna está dedicada en el Journal a la evocación de la lucha guerrillera emprendida por "el incansable Merino que acaba de hacer trizas un destacamento de la columna constitucional del Empecinado en los alrededores de Castel-de-Peones ${ }^{84}$. Ese jefe espanta a los constitucionales hasta el punto de que varias tropas del Empecinado ahora no desean luchar contra él". Después del combate victorioso contra los hombres del Empecinado, Merino mandó ejecutar unos prisioneros (13 de junio). En el Journal, no se critica la crueldad del cura a pesar de haber cometido una violación del código de la guerra.

Una carta escrita en Bayona, el 2 de julio, trae una noticia favorable a Merino: en el mismo momento en el que se anunciaba en Bayona "la extinción total de Merino y de su tropa", llegó de Madrid la información de que aquel valiente cura acababa de hacer prisioneros 40 dragones del ejército patriótico (sic) (14 de julio).

Evitando dar la impresión peyorativa de que Merino recluta preferentemente granujas, aventureros o pobretones, en el Journal se informa, a principios de agosto (8 de agosto), de que "se le unen cuatro carmelitas, un cura, un capitán retirado y ocho campesinos", o sea un amplio abanico social, por así decir, con eclesiásticos, militares y campesinos, pero con la ausencia de aristócratas, burgueses y funcionarios. Unas semanas antes, se había mencionado la inclusión de la juventud dispuesta a luchar al lado de Merino (19 de julio).

Hubiera sido una labor de nunca acabar el elaborar la lista de los líderes absolutistas no citados en el Journal. Esto pone de relieve el contraste entre la importancia conferida a Merino -como se vio- y las escasas menciones, por ejemplo, de Eroles o de Mataflorida. Tomaré el único ejemplo, sin desarrollarlo, de uno de esos absolutistas ignorados por el Journal de manera, o calculada, o involuntaria si no llegó a París la suficiente información: aludo al general Elío a

82 Lugar de nacimiento de Merino.

83 Puede tratarse de Salvatierra de Tormes (provincia de Salamanca), más bien que de Salvatierra de Esca (provincia de Zaragoza).

84 Castil de Peones, provincia de Burgos. 
quien Encarna Garcia Monerris y Carmen Garcia Monerris han dedicado un importante artículo 85 .

\section{LOS MILITARES}

Dado que la revolución de 1820 ha sido iniciada y llevada a cabo por el ejército regular, era previsible y necesario que éste se pusiera al servicio del nuevo régimen para sostenerlo y eliminar a los oponentes.

Con la posible sorpresa para los lectores del Journal, las referencias a los diferentes componentes de la fuerza militar ocupan un gran espacio en el diario a lo largo de 1821.

Respecto a los guardias de corps, supongo que, durante el año anterior, esos guardias encarnaban la fidelidad y la devoción hacia el monarca cuyo antiliberalismo parecía probable y llamado a prolongarse.

Cuando en Madrid, el 5 de febrero, los guardias oyeron el detestable grito ¡Viva el rey constitucional!, intervinieron y acabaron disparando. Inmediatamente, se armó la guarnición y, cuando los guardias estuvieron acuartelados, fueron los alabarderos los que sustituyeron a los guardias de corps, impopulares para los liberales (17 de febrero).

Por eso, los partidarios del nuevo régimen aplaudieron, a mediados de febrero, cuando unos guardias de corps, por supuesto minoritarios, evadidos de su cuartel asediado, se presentaron, para demostrar su adhesión a las nuevas autoridades, o a la guardia nacional, o al municipio, o al ministerio de la Guerra.

Predomina la impresión de la impopularidad selectiva de los guardias de corps, probablemente porque su convivencia con el rey lleva a imaginar que compartian su hostilidad hacia los liberales y el nuevo régimen. El 7 de agosto, "un batallón del $1^{\circ}$ regimiento de la guardia (de corps) se encaminó hacia al Pardo donde se iba a pasarle revista. Pero, como, en las calles, se cantaba el himno de Riego, el comandante del batallón ordenó que cesara esa música y que se la sustituyera por otra. Los testigos tuvieron la confirmación de que la guardia y las milicias se han mostrado un poco opuestas al sistema actual" (25 de agosto).

E1 20 de agosto, al anochecer, ocurrió un incidente también en la capital: "Varias personas se pusieron a cantar el Trágala debajo de las ventanas de unos guardias de corps encarcelados como acusados de haber insultado al pueblo durante los desórdenes que estallaron unos meses antes". Un oficial envió algunos soldados para eliminar ese grupo indeseable, pero esos militares, al oír los insultos más groseros, repartieron algunos golpes con las culatas de sus fusiles (2-3 de septiembre).

Se perfila, pues, la idea de que, en el seno de la guardia de corps, la mayoría de los miembros son unos determinados antiliberales, mientras que sólo una minoría -como vimos- se ha atrevido a dar a conocer su adhesión al nuevo régimen.

85 "Escribir y conspirar: el perfil de un reaccionario (Francisco J. Elío, 1767-1822)", en el libro coordinado por Encarnación García Monerris y Carmen García Monerris: Guerra, revolución y constitución, op. cit., pp. 385-407. 
Por otro lado, aunque no se emplea para calificarles el término "exaltado", a esa categoría tal vez mayoritaria, parecen pertenecer los activos y, a veces, atrevidos miembros de la milicia nacional ${ }^{86}$.

En los primeros dias de enero, el responsable del Journal recibe una carta escrita en Bayona, en la que se lee:

Habiéndose establecido los descontentos en los montes cerca de Tolosa, el jefe político de Gutuzcoa (sic) ha requisado dos compañias de guardias nacionales de San Sebastián y de Tolosa (...). Esos mismos descontentos han detenido el correo de Madrid cerca de Vitoria (...). Las bandas empiezan a propalarse por España y la gente no se atreve a viajar sin escolta (3 de enero).

A mediados de enero, los guardias nacionales de Galicia y de Andalucía empleados en la persecución de los insurrectos -no se precisa a qué bando pertenecen- habian protestado en voz baja, porque no querian prestar un servicio que concierne exclusivamente a la tropa de linea (29-30 de enero).

Poco después, por un motivo no aclarado, se produce una refriega, no se sabe dónde, con la tropa de línea. También se ignora si a los guardias nacionales les agradó, o no, perseguir al absolutista Abuelo (2 de febrero y 27-28 de enero). En agosto, se señala que las milicias, al lado de los guardias nacionales, se han mostrado "un poco opuestas al sistema actual", por parecerles éste -se suponedemasiado moderado (25 de agosto).

Mucho más tarde, a finales de noviembre, se alude a unas disensiones en el seno de la guardia: los propietarios, los negociantes y los empleados están "resueltos a mantener el orden y a sostener al gobierno", pero se oponen a los amigos de la Fontana de Oro y a los partidarios de un levantamiento $\left(1^{\circ}\right.$ de diciembre). En definitiva, en oposición con los guardias de corps mayoritariamente antiliberales y apegados al rey, los guardias nacionales parecen, globalmente, pro-liberales, pero no exaltados $y$, menos aún, revolucionarios.

A principios de diciembre, "en Madrid, el soldado está a favor de S.M. e igualmente parte de la milicia", lo que confirma que otra parte de ella suele desconfiar del monarca demasiado moderado como se ha dicho, o, peor todavia, cómplice de los absolutistas.

En Cádiz, que encabeza contra el gobierno la insurrección anti-absolutista más radical y espectacular, se distinguen, a finales de noviembre, "las milicias que están todas armadas y forman un cuerpo magnífico":

"Alternan con las tropas de la guarnición (...). Un batallón está situado en el puente (de) Zuazo. Durante la noche, todas las puertas están cerradas. Los

86 Joaquin Ruiz de Morales, Historia de la Milicia Nacional desde su creación hasta nuestros dias, Madrid, Prats y Ruiz, 1855. Juan Sisinio Pérez Garzón, Milicia nacional y revolución burguesa, Madrid, CSIC / Instituto "Jerónimo Zurita”, 1978. Pablo Casado Burbano, Las fuerzas armadas en el inicio del constitucionalismo español, Madrid, Editorial Revista de Derecho / Editoriales de Derecho Reunidas, 1982, pp. 136-14. José María García León, La milicia nacional de Cádiz durante el Trienio Liberal, 1820-1823, Cádiz, Caja de Ahorros, 1983. En el Journal se ha de lamentar la anómala asimilación de "milicianos" y de "guardias nacionales". Pido disculpa por haber renunciado a operar esa diferenciación mediante una larga investigación que no he emprendido al respecto. 
habitantes han construido unas fortificaciones en la Puerta de Tierra (sic). Se acaba de colocar una batería de once cañones para defender el puente (de) Zuazo" (3-4 diciembre).

Imposible saber por qué, en los disturbios que se producen en Pamplona en diciembre, "los granaderos de las milicias son insultados" (17-18 de diciembre).

En otro orden de cosas, parte de la información relativa al ejército regular aborda dos temas: el sorteo y los sueldos ${ }^{87}$ :

El 26 de julio, se advirtieron en Valladolid los síntomas de una insurrección cuando se verificó el sorteo para la designación de los sustitutos para el ejército en actividad. Un centenar de hombres se presentaron en la plaza mayor con una bandera y un tambor, lanzando canciones antipatrióticas (...). Intervino la tropa de línea (16 de agosto).

En enero, los jefes políticos y los comandantes militares de todos los sectores habian escrito que los fondos estaban agotados y que no podian responder a las necesidades más urgentes (11 de enero).

En noviembre, la protesta contra la insuficiencia de los sueldos está a punto de provocar insurrecciones. En el artículo del Journal, el comentario es muy severo: "Los soldados pueden derribar la Constitución tras haberla instaurado, aunque han sacado enormes ventajas del nuevo régimen: abolición de cuerpo de los cadetes e igualdad para el reclutamiento" ( $1^{\circ}$ de diciembre).

Los militares están mal pagados y alimentados, y, por eso, se llega a oír la anónima y desvergonzada sugerencia: "No os faltará nada, se les dice; el saqueo de las iglesias y de los serviles os abrirá la posibilidad de asegurar con abundancia vuestro sueldo y vuestra subsistencia" (16 de diciembre).

Quizá por ser un tema dificil de enfocar y de analizar, casi no se cita en el Journal las opiniones de los soldados. Sólo en mayo, se señala que, en Madrid, les indigna "la cautividad" a la que está sometido el rey. Ya vimos cómo, en la capital, en diciembre, "el soldado está a favor de S.M." (17-18 de diciembre) pero, en el mismo artículo, se cuela una noticia sorprendente que concierne exclusivamente a los oficiales y no a los soldados rasos: en varias ciudades no mencionadas, "la facción de los comuneros" tiene discipulos dispuestos a insurreccionarse: Casi todos los oficiales están involucrados y también parte de las milicias de las provincias.

De nuevo, imposible saber a qué cuerpo pertenecían los soldados que, en Zaragoza, "suelen tocar la retreta y que se han reunido (a finales de julio) al pie de la piedra de la Constitución”, signo, lógicamente, de un respetuoso homenaje y de la sumisión de esos militares al régimen liberal. Pero esa actuación provocó "una réplica de los descontentos que tiraron una lluvia de piedras" hacia los culpables (6-7 de agosto).

Al final del año, el balance es más sombrío que nunca, porque se ha extinguido la solidaridad entre las unidades; se degrada la estricta obediencia debida a los superiores; se ha hecho papel mojado la afirmación de Riego según el

87 Cf. José Cepeda Gómez, El Ejército en la política española (1767-1843). Conspiraciones y pronunciamientos en los comienzos de la España liberal, Madrid, Fundación Universitaria Española, 1992. 
cual la revolución ha permitido el acceso del militar al estatuto soñado de ciudadano.

En Navarra, en plena insurrección al final de 1821, "la cantidad de habitantes armados va creciendo cada día", pero, en Pamplona, los mil o novecientos hombres armados y bien equipados parecen estar a las órdenes de una junta llamada apostólica, y los soldados encargados de derribar a esos adversarios repartidos en guerrillas no son más numerosos que ellos (29 de diciembre).

\section{EL CLERO Y LA RELIGIÓN}

El examen de los numerosos artículos del Journal referidos a ese tema confirma tres ideas fundamentales e incontrovertibles: que la mayoría del clero es hostil a la revolución, que los liberales, en su conjunto, manifiestan hacia él desconfianza $u$ hostilidad y que el Journal adopta el punto de vista de los antiliberales $^{88}$. Así, en el número de los 22 y 23 de octubre, nada menos que cuatro columnas están dedicadas a enfatizar y celebrar el comportamiento y las tomas de posición de los prelados y de los monjes. Las alabanzas alcanzan su punto culminante cuando una epidemia de fiebre amarilla asola Cataluña e incita al clero a portarse con una ejemplar actividad, espíritu de sacrificio y generosidad; el articulista resaltó entonces -como veremos- el desvelo del obispo y de los párrocos y de las monjas (23 de noviembre).

\subsection{La actuación pacífica del clero}

En el verano, cuando se intensifica en Barcelona la venta de rosarios, de crucifijos y de indulgencias, el articulista advierte que "el clero sigue teniendo una gran influencia sobre los habitantes del campo" (4 de agosto).

Interesa dar a conocer, por su importante significado, lo que pasó en Toledo, el 14 de junio: "La procesión de Nuestra Señora de la Esperanza, que sale, cada año y en la misma época, de la iglesia de San Cipriano, se encaminó, conforme a la tradición, hacia el convento de los capuchinos donde la recibieron los monjes. Apenas salió del convento la procesión para volver a San Cipriano cuando mil voces repitieron los gritos de “¡Viva la esperanza! ¡Viva la religión! ¡Viva el guardián de los capuchinos! ¡Viva la catedral de Toledo! ¡Viva el rey! ¡Abajo la constitución y los liberales que la quieran!” (30 de junio). Esa cita tiene un interés especial, porque en esos gritos se agrupan, sin que se perfile un reparto jerárquico, todos los componentes del credo de los realistas y se puede suponer que los civiles realistas coinciden con los eclesiásticos

88 Gaspar Feliu i Montfort, La clerecia catalana durant el trienni liberal, Barcelona, Institut d'Estudis Catalans, 1972. Manuel Revuelta González, Politica religiosa de los liberales en el siglo XIX. El Trienio constitucional, Madrid, CSIC / Escuela de Historia Moderna, 1973 (libro fundamental de más de 500 páginas, con mucha documentación). A. Gil Novales, El Trienio liberal, op. cit., pp. 35-36. Gérard Dufour, Estudio preliminar a Sermones revolucionarios del Trienio liberal, Alicante, Instituto de Cultura "Juan Gil-Albert", 1991. Emilio La Parra López, "Belligeranza del clero contro il liberalismo nella Spagna del Triennio liberale (1820-1823)", en Alfonso Botti, Clero e guerre spagnole in età contemporanea (1808-1939), Torino, Rubbetino Editore, 2011 , pp. 167-184. Emilio La Parra y María Ángeles Casado, La Inquisición en España. Agonía y abolición, Madrid, Los libros de la catarata, 2013, pp. 153-171. 
organizadores de la procesión. Para ellos, se trata de defender la religión amenazada, de detener la persecución del clero, de apoyar al rey, de rechazar el constitucionalismo y de declarar la guerra a los liberales. Conforme progresaba la procesión, todo el pueblo repetía esos gritos, en particular cuando pasaba delante de las casas de los liberales. Cuando los guardias nacionales trataron de dispersar la procesión, fueron desarmados y pisoteados.

La actuación legal del clero consiste, como aquí, en organizar procesiones y también en participar en las elecciones de los diputados a Cortes. Pero, en algunos sectores geográficos, sin hacer colectivamente rancho aparte, los eclesiásticos renuncian a votar, como en la Mancha, a principios de marzo: "Las autoridades militares, el jefe politico, el obispo, el clero, la nobleza e incluso los campesinos están acusados de haber dado señales de indiferencia hacia el sistema constitucional" (30 de mayo).

A mediados de noviembre, el día de las elecciones, en una aldea de la Mancha, el alcalde, supuestamente liberal, pidió al cura que cantara el Te Deum, pero, quizás para sugerir el posible resultado catastrófico para los liberales, el cura replicó cantando el oficio de difuntos (24 de noviembre).

Imposible, en el Journal, hacerse una idea, ni siquiera esquemática, del reparto de los eclesiásticos elegidos diputados entre pro-liberales y antiliberales. La oposición parece encabezada por "el arzobispo de Tarazoa", en realidad el obispo de Tarazona, "ex inquisidor y firmante de la declaración contra la constitución, firmada por 69 diputados llamados Persas" (30 de marzo). En una sesión secreta de las Cortes, el prelado sostuvo que se negaba a someterse a un decreto de las Cortes, por estar resuelto a someterse exclusivamente a la jurisdicción del papa. Se teme un cisma en el seno de los obispos, porque algunos de ellos, recién nombrados, no están reconocidos por el Vaticano (11 de agosto). Tales son los casos de "Mugnoz Torrejo", en realidad Diego Muñoz-Torrero, obispo electo de Guadix ${ }^{89}$, y de "Espiga”, en realidad José Espiga y Gadea, nombrado arzobispo de Sevilla90.

Curiosamente, dada la orientación del Journal, resulta difícil de explicar el buen tratamiento reservado al obispo de Mallorca: en la apertura de las Cortes extraordinarias el 28 de septiembre, tomó la palabra al final del discurso del rey. El prelado empezó agradeciendo al monarca por haberse presentado voluntariamente ante los representantes de la nación. Según el obispo, la nación española aborrece tanto la arbitrariedad como la anarquía. Como forma de gobierno, sólo quiere "la monarquía templada, tal como la establece la Constitución". Por fin, "ama y respeta de manera soberana (sic) la inviolable y sagrada persona de S.M." (13 de octubre). O sea que, pidiendo prestados conceptos y enunciados, al mismo tiempo, a los liberales moderados y a los absolutistas, el obispo intenta hacer compatibles los derechos inviolables del monarca (enfoque de los absolutistas) y la obligatoria sumisión a la Constitución (actitud dictada por los liberales).

89 Gil Novales, Diccionario, op. cit., t. II, 2126.

90 Gil Novales, Diccionario, op. cit., t. I, pp. 980-981. 


\subsection{El clero como víctima}

Parece incuestionable que la mayoría de los hombres de Iglesia se consideran maltratados por "la constitución civil del clero" demasiado semejante a la que se instauró en Francia durante la Revolución (21 de octubre). Pero, pronto se notó que las medidas anticlericales no eran tan bienvenidas y populares como lo habian imaginado las nuevas autoridades: "El decreto de supresión de las religiosas" (sic), es decir de los conventos para monjas, firmado por el rey ha quedado como papel mojado, lo que permite suponer que su puesta en ejecución no resulta tan anhelada por la mayoría de la nación española, como se suele adelantar (2 de febrero).

En Burgos, el jefe político o prefecto (sic) ha mandado cerrar 17 conventos, bajo el pretexto de que eran centros de conspiración: "Es exactamente lo que se decía en nuestro país ${ }^{91}$ en $1791 "$ (12-13 de febrero).

A mediados de marzo, en muchas gacetas españolas figuran las largas listas de los bienes de las órdenes monásticas suprimidas, que están en venta. Pero se dan a conocer pocos compradores, tal vez porque "el clero ha propalado la idea de que todos los adquisidores serán excomulgados" (30 de marzo). Las ventas tienen lugar sobre todo en Cataluña y en los alrededores de Cádiz.

En el otoño, se advierte, en general, que "los sacerdotes están especialmente expuestos a la severidad de los revolucionarios españoles"; hubo varios encarcelamientos y envíos al presidio de Mallorca (2 de septiembre). El empleo del término infame "revolucionarios" permite imaginar que los inspiradores y ejecutantes de esas medidas no son los liberales moderados. La primera frase del párrafo siguiente, escrito a principios de febrero, es irónica, mientras que los enunciados ulteriores son denunciadores:

El clero sigue recogiendo en España y en Nápoles los sabrosos frutos del nuevo régimen. El obispo de Oviedo, don "Gregoire Ceruedo de la Fuente"92, que estaba a la cabeza de la diócesis a partir de 1815, ha sido privado de sus ingresos y excluido de su diócesis como enemigo del régimen constitucional. Cuando se marchó, mandó cantar un Te Deum en su capilla y se retiró a León" (12-13 de febrero).

\section{LOS ESPAÑOLES REFUGIADOS EN FRANCIA}

Varias posibilidades se ofrecen a los habitantes para hacer pública su oposición al nuevo régimen:

- tomar las armas e ingresar en las partidas de guerrilleros,

- expresar sus opiniones en las elecciones,

- participar en las manifestaciones callejeras violentas o pacíficas.

Si se estiman amenazados, para escapar a las detenciones, se pueden resignar a refugiarse en el extranjero, Francia principalmente, donde algunos se agruparán en Toulouse en torno al marqués de Mataflorida o del marqués de

91 En francés: "Chez nous".

92 Gregorio Ceruelo de la Fuente: Gil Novales, Diccionario, op. cit., t.I, p. 703. 
Eroles $^{93}$. Como era previsible, en cuanto a los refugiados, en el Journal predominan numéricamente los eclesiásticos maltratados por los "jacobinos", los anticlericales y los ateos que han usurpado el poder.

En marzo, llegan a Bayona unos refugiados que proceden de todos los sectores de la península. Se les invita a "internarse", es decir a alejarse de la frontera:

El general de la orden de los capuchinos, de 72 años de edad, y muy respetable por sus virtudes, ha llegado a Bayona. Ese prelado ha sido proscrito de su patria por un decreto de las Cortes en consecuencia de una pastoral juzgada subversiva por la censura. La Miscelánea ha denunciado ese rigor y esa crueldad (12-13 de marzo).

A mediados de abril, se anuncia que el general Fournas ${ }^{94}$ ha sido autorizado a refugiarse en Francia. Ha llegado a Perpiñán sin haberse expuesto a peligros (20 de abril). A finales del mismo mes, llega a Bayona el obispo de Tarragona, de 70 años de edad, ex inquisidor, expulsado de España. Le acompañan dos eclesiásticos y un criado. Ha sido escoltado hasta Irún por quince cazadores a caballo (28 de abril).

En mayo, se espera en Bayona a "Solechaga" (Solchaga), navarro de origen noble 95 . Unos días después, se alude a "Solchago" llegado en compañía de cuatro monjes de su orden. Se alojará en los alrededores de la ciudad (11-12 de junio). Las autoridades locales han reservado una acogida sumamente cordial y generosa a esos "desgraciados y respetables eclesiásticos". Otros nueve capuchinos, entre ellos tres del convento de Valladolid, llegarán a Bayona a finales de junio y finales de julio (5 de agosto).

A mediados de agosto, las autoridades de San Sebastián han dirigido hasta la costa francesa las tripulaciones de dos barquichuelos que tratarán de detener a un personaje importante, cuyo nombre no se menciona, que, en barco, se dirigia hacia el país vecino (27-28 de agosto).

A principios de septiembre, escribe al Journal un español desconocido residente en Irún: "La estancia de varios refugiados españoles en Bayona

93 Se han excluido los estudios referidos exclusivamente a la emigración liberal: José Luis Comellas, Los realistas en el Trienio, op. cit. Gérard Dufour, Juan Antonio Llorente en Francia (1813-1822), Genève, Ed. Droz, 1982. Jean-René Aymes, "Españoles en Francia (1789-1823): contactos ideológicos a través de la deportación y del exilio", Trienio, n¹0, 1987, pp. 3-26. Aline Vauchelle-Haquet, "Un afrancesado refugiado en Francia, Vicente Gonzalo Arnao", Trienio, $\mathrm{n}^{\circ}$ 9, 1987, pp. 177-185. Juan López Tabar, Los famosos traidores. Los afrancesados durante la crisis del Antiguo Régimen (1808-1833), Madrid, Biblioteca Nueva, 2001, pp. 180-269. Juan B. Vilar, La España del exilio. Las emigraciones politicas españolas en los siglos XIX y XX, Madrid, Editorial Sintesis, 2006, pp. 140-144. Jean-René Aymes, "Los afrancesados en París (1750-1850)", en F. Martínez, J. Canal y E. Lemus, Paris, ciudad de acogida. El exilio español durante los siglos XIX $y$ XX, Madrid, Marcial Pons Historia, 2010, pp. 15-39.

94 Blas de Fournas de Labrosse, nacido en Narbona, había sido declarado responsable de la muerte de miles de habitantes víctimas de una epidemia de fiebre amarilla. Pasó a Cataluña, pero fue expulsado de Barcelona a principios de abril: Gil Novales, Diccionario, op. cit., t. I, pp. 11421143.

95 Fray Francisco de Solchaga -como lo expone A. Gil Novales- "se expatrió por Irún en mayo de 1821 y formó parte de la Junta Realista de Bayona en 1822, encargada de preparar la invasión francesa": Gil Novales, Diccionario, op. cit., t. III, p. 2904. 
fomenta, según se dice, unas grandes inquietudes en nuestro gobierno. Se afirma que están relacionados con varias ciudades de España y que disponen de mucho dinero" (15 de septiembre).

Varios meses después, a finales de diciembre, cambia de significado, por primera vez, la información acerca de los refugiados que afluyen más que nunca a Bayona. En efecto, se trata ahora de personas que sólo se dedicaban al comercio y que, hasta ahora, consideraban con indiferencia "los cambios politicos (...). Hoy, piensan de manera distinta" y algunas, habiéndose enriquecido en su país, pasan a Francia para esperar alli "el término de los acontecimientos". Viven en el temor de "la exageración del partido liberal" (sic) (30 de diciembre).

\section{LA OPINIÓN PÚBLICA, LA PALABRA ORAL Y ESCRITA}

El examen cronológicamente ordenado de las opiniones de los habitantes, tales como las evoca el Journal a lo largo de 1821, lleva a estimar que la impopularidad del régimen liberal no cesa de ir en aumento.

A principios de enero, un ex Consejero de Castilla escribe que "son muchos los defensores del antiguo régimen y conservan bastante influencia". Según él, son ellos los que "fomentan disturbios en Andalucia, Castilla, Cataluña, Galicia y Aragón". Por eso, el pueblo desaprueba las innovaciones que pretenden ser atractivas. Adviértase que se excluye que esos trastornos se puedan achacar a los liberales "exaltados" o a los "revolucionarios".

En contradicción con lo que veremos en artículos muy posteriores en los que se resaltará o celebrará la determinación y la fuerza de los habitantes opuestos al nuevo régimen, figura un párrafo excepcional en el que se comenta casi con simpatía el credo y los anhelos de unos ciudadanos no designados como liberales -hay que apuntarlo- sino, sencillamente, como unos patriotas que sueñan con una "revolución" ni tumultuosa, ni destructora: "España está hoy en el punto en el que estaba Francia en 1789; los patriotas hacen alarde de querer emprender una revolución suave y pacífica; hablan de su celo para fomentar la felicidad pública ${ }^{96}$ y se enfadarían si se pusiera en tela de juicio su apego a la religión y al rey". Lo más extraño es que esos "patriotas", a pesar del ejemplo de lo que pasó en Francia, hallan gente dispuesta a creer en sus "protestas": se entiende que protestan cuando se les acusa de manera injusta e inadmisible (14 de enero).

Es de notar cómo, en esos inicios del año, el Journal no duda en contar, se supone con disgusto o inquietud, que el nuevo régimen odiado conserva defensores, aunque sean minoritarios. Así se lee el comentario siguiente, posiblemente portador de una pizca de ironía: "España es el país de la Constitución. La gente se ha acostumbrado a esa clase de producción, ya que acaba de nacer una para las mujeres" (18 de enero).

Entre los silencios mantenidos por el Journal acerca de los numerosos aspectos de la exteriorización de la vida política, conviene señalar que no se alude nunca al "belle sexo" como si las señoras, por indiferencia o incapacidad intelectual, vivieran ajenas a esa realidad monopolizada por los varones. Ahora bien, Juan Francisco Fuentes y Pilar Gari han transcrito un artículo publicado por el diario de El Espectador del 4 de mayo de 1821, en el que unas

96 En francés: "Bien public". 
representantes del bello sexo (sic) se disponen a imitar los héroes de la patria Riego, Quiroga y otros ${ }^{97}$.

En marzo, procedentes de varias regiones, coinciden las noticias que resaltan la impopularidad del nuevo régimen o, por lo menos, la falta de apoyo. Así, en Andalucía, "se esfuma el primer entusiasmo", porque la gente se da cuenta de que ese régimen sólo favorece a unas cuantas personas. En la Mancha, se observa una extraña convergencia de antiliberales pertenecientes a varias clases de ciudadanos: "Están acusados de indiferencia ante el sistema constitucional los militares de alta graduación, el jefe político, el obispo, el clero, la nobleza y los campesinos" (30 de marzo).

El diputado Navarro (imposible de identificar en ausencia del nombre de pila) confirma la convergencia de opinión del clero y de la población rural:

La gran provincia de Valencia resulta como borrada del mapa constitucional. En muchas parroquias no se ha pronunciado el nombre de Constitución desde el púlpito evangélico. Los campesinos consideran heréticos los partidarios del sistema constitucional, y creen que están excomulgados los miembros de las Cortes (25 de marzo).

A principios de junio, en el análisis de los componentes de la opinión pública, por primera vez en el Journal, se opera una diferenciación que tiene en cuenta al mismo tiempo la diversidad territorial y el origen social de los habitantes. Así, los campesinos rechazan el nuevo régimen, en particular porque son víctimas de los milicianos tenidos por judios (sic) y acostumbrados a imponer rescates costosos para poner en libertad a los detenidos. Según los oradores liberales, ese odio vehemente es también "un efecto del fanatismo de los párrocos" (16 de junio).

En un artículo referido a Madrid en julio, la imagen del pueblo comprometido en la agitación política es peyorativa, porque, en una primera fase, llegó a renunciar a su ideal y a su credo ancestral: "El pueblo sólo deseaba un cambio de sistema en el gobierno; tiene un respeto religioso de la realeza y un amor sincero para el rey", pero no se daba cuenta de que "rompía con sus manos todos los vínculos sociales y dejó el trono sin apoyo (19 de julio).

Unos meses después, en una "carta particular" se combinan un motivo de satisfacción y otro de decepción e inquietud: "Las nueve décimas partes de la nación desean, de un modo u otro, la vuelta a la anterior situación de prosperidad bajo la monarquía", pero los abusos durante seis años (1814-1820) impiden que, en el principal sector de la nación, se llegue a un acuerdo (29-30 de octubre). Ese sorprendente enunciado final llama la atención, porque, por un lado, parece valorar la actuación laudable de Carlos III y de Carlos IV, pero, en unión implícita con los liberales del Trienio, se lamenta las faltas y los errores cometidos por Fernando VII después de la Guerra de la Independencia.

A mediados de diciembre, se completa en el Journal el panorama espacial evocado en enero, nada sorprendente para los observadores actuales: en "Álava, Castilla la Vieja, Navarra, Guipúzcoa y Vizcaya, se multiplican las declaraciones de fidelidad al Rey, enviadas a él" (17-18 de diciembre). A finales del mes, sigue

97 J. F. Fuentes y P. Gari, Amazonas de la libertad. Mujeres liberales contra Fernando VII, Madrid, Marcial Pons Historia, 2014, p. 67. 
en aumento la oposición al sistema liberal, como lo ilustra el caso de una insurrección en Orense dirigida, como en otras ciudades, contra los llamados "republicanos" y contra los milicianos cuyo desarme exige la población: "El pueblo furioso, gritando contra algunas personas acusadas de republicanismo, ha quebrado a pedradas los cristales de sus casas y ha amenazado a varios individuos conocidos como jacobinos" (27 de diciembre).

A los ojos de los articulistas del Journal parece evidente que el nuevo régimen está en descomposición y que le falta la adhesión de la mayoría de los habitantes: Andalucía sigue insumisa, Navarra está en plena insurrección y, en las provincias vascongadas, los habitantes lamentan la situación que reina en España, la cual está en "un estado real de guerra civil y de anarquía" (22 de diciembre).

En una "correspondencia particular" redactada en Madrid el 19 de diciembre, el autor estima que se ha llegado al punto más temible: "Se ha iniciado la guerra civil con sintomas terribles" (22 de diciembre).

\subsection{La prensa}

El desarrollo espectacular de la prensa a partir de 1820 ha sido resaltado atinadamente por A. Gil Novales: "Las noticias y las famas, las críticas y las esperanzas circulan rápidamente en el Trienio liberal. Esta fue la labor fundamental de la prensa y de los folletos, amplificada su acción mediante la lectura colectiva"98. De manera excepcional, porque se conoce la incompatibilidad de sus consideraciones historiográficas respectivas, José Luis Comellas coincidió implícitamente con A. Gil Novales cuando escribió: “(...) La fiebre de las publicaciones periódicas alcanzó su nivel más alto (...). Se fundaron publicaciones destinadas a lectores de todos los niveles culturales y social...hasta a casi analfabetos"99.

El rechazo categórico e indiferenciado de la prensa española acusada de carecer totalmente de interés se comenta a mediados de agosto en el Journal: "Los diarios sólo se dedican a discursos declamatorios demagógicos más espantosos unos que otros. No se respeta nada y las hipótesis más horrendas se presentan como certidumbres" (18 de agosto).

Gracias a la libertad de prensa, se multiplican los diarios que distan mucho de sintonizar. Es lo que se comenta en el Journal en agosto. Están implicados El Censor $^{100}$ calificado de reaccionario por J.L. Comellas y A. Gil Novales, mientras

98 El Trienio liberal, op. cit., p. 78. Sobre la prensa, cf. como estudios generales: A. Gil Novales, "La prensa en el Trienio liberal (1820-1823)", en Prensa y sociedad (1820-1836), V Coloquio de Pau / Madrid, 1975, pp. 201-206. Del mismo autor (dir.) La prensa en la revolución liberal: España, Portugal y América Latina, Madrid, Universidad Complutense, 1983. María Cruz Seoane, Oratoria y periodismo en la España del siglo XIX, Madrid, Fundación Juan March / Editorial Castalia, 1977 e Historia del periodismo en la España del siglo XIX, Madrid, Alianza Editorial,1996, pp. 77-107. J. Fernández Sebastián y J. F. Fuentes, Historia del periodismo español: Prensa política y opinión pública en la España contemporánea, Madrid, Sintesis, 1997.

99 J. L. Comellas, El Trienio Constitucional, op. cit., pp. 37-38.

100 Sobre El Censor, cf. Claude Morange, "Teoría y práctica de la libertad de la prensa durante el Trienio constitucional: el caso de El Censor", en Siete calas en la crisis del antiguo régimen español, Alicante, Instituto de Cultura "Juan Gil-Albert", 1990, pp. 87-105. A. Elorza La 
que El Universal es el más progresista de todos los diarios de los afrancesados, en palabras de J.L. Comellas: "Se va a crear un nuevo diario, redactado por los redactores de El Censor y -según se dice- bajo la dirección inmediata de los Infantes de don Carlos y don Francisco. El objetivo es oponerse al El Universal" 101.

El autor desconocido de una carta escrita en Irún a principios de agosto declara la guerra a los diarios convertidos en "ecos fieles de las elucubraciones filosóficas de los clubistas": "Según El Espectador, España no está todavía a la altura de los principios realmente liberales". Y viene una cita, escandalosa para el Journal, sacada del diario español: "Todo cuanto está vinculado a la monarquía y a las ideas religiosas es incompatible con la verdadera libertad" (19 de agosto). A mediados de noviembre, actúan los liberales más exaltados cuyo odio se ejerce contra el reaccionario El Imparcial dirigido por Javier de Burgos y contra El Censor (24-26 de noviembre).

En el Journal, como si se quisiera ocultar la extraordinaria proliferación de la prensa pro-liberal, sólo se menciona dos veces el Eco de Padilla, "diario de los descamisados (sic)". Para que los lectores franceses entendieran el sentido de ese término, se propuso el equivalente "sans chemises ou sans culottes", expresión que designaba, durante la revolución, a los agitadores parisinos de clase popular. El Eco de Padilla anunciaba que "una verdadera revolución se verificará dentro de un mes, como máximo" (24 de noviembre). También se había leído en El Eco de Padilla a mediados de agosto: "Dice positivamente que hay que derribar cuanto se ha establecido sin excepción y reconstruir otro edificio cuyas bases serían la libertad y la igualdad" (19 de agosto).

En el Journal de aquel día se transcribe una breve e indefinida noticia procedente de Irún según la cual se ha publicado - no se dice dónde- una "hoja" (sic) escrita en francés en la que el autor se desahoga, no sólo contra la tiranía (sic) de España, sino también contra las monarquías. Ese diario o periódico -se lee en el Journal- sería "Le Régulateur, escrito en francés, en el estilo más revolucionario". Lo denunció el embajador de Francia porque se habian formulado discursos aborrecibles contra la familia real francesa; el embajador consiguió su prohibición y el arresto del redactor.

Aunque quedaba abierta para los articulistas del Journal la posibilidad de referirse repetidas veces a los diarios pro-liberales, a excepción del Eco de Padilla, con la finalidad de desmentir las afirmaciones enunciadas en toda esa prensa aborrecida y de replicar a las opiniones inadmisibles allí expuestas, sólo una vez -que yo sepa- se menciona, a principios de agosto, el Diario Constituzional (sic) de Barcelona, claramente hostil al clero regular: "Acusa a todos los monjes dominicos de Manresa, recién suprimidos, de haber proporcionado al monje

modernización politica, op. cit., pp. 153-165. J. Varela Suanzes-Carpegna, La monarquía doceañista, op. cit., pp. 305-309.

101 Agustín Martínez de las Heras, "Los periódicos afrancesados, absolutistas y ultras vistos desde El Universal (1820-1823)", en Sociedad y liberalismo en la España del siglo XIX - Homenaje al profesor Alberto Gil Novales (coord. Juan Francisco Fuentes), Lleida, Milenio, 2001, pp. 103115. 
Fulset la oportunidad de reclutar su tropa" en el seno de la población rural (4 de agosto).

\subsection{La literatura}

Interpretando el Sexenio 1814-1820 como un siniestro periodo de extinción de las luces, los liberales del Trienio presumen de ser los descendientes de los ilustrados del siglo XVIII y, por eso, proclamaron la libertad de prensa que ellos van a aprovechar todo lo posible, pero con la obligación, lastimosa para ellos, de admitir que los oponentes también se valdrán de esa libertad.

En tres ocasiones, el Journal ve exclusivamente en la proliferación de todas clases de libros y folletos el predominio de los textos subversivos, inmorales, irreligiosos, a veces importados del extranjero. Se lee en una carta escrita en Madrid: "Una licencia desenfrenada ha sucedido aquí a la severidad que reinaba en los reglamentos de la librería y las obras más obscenas se venden públicamente sin que la autoridad intervenga para impedirlo" (8 de abril).

En el marco de una ofensiva anticlerical, se constata una profusión de "catecismos", denominación que invita a pensar que se trata de unos breviarios doctrinales referidos a la Constitución, a las Cortes o a las nuevas leyes. Los lectores del Journal tampoco tendrán la posibilidad de adivinar el contenido de unos llamados "opúsculos de estilo popular" (19 de julio). En el verano, corre por la capital "un torrente de libros malos y de opúsculos incendiarios" (25 de agosto).

En la misma época, las acusaciones proferidas en el Journal apuntan a las Cortes que han votado fondos para "favorecer la traducción e impresión de todos los libros que la impiedad y la anarquia han engendrado en la Francia de 1793". En España, un diputado ha propuesto la conversión de los púlpitos cristianos en tribunas populares para que en ellas se prediquen los derechos del hombre en lugar de los pretendidos derechos de Dios" (19 de agosto). Por supuesto, el epíteto "pretendidos" se atribuye aquí al habla infamante de los liberales.

\subsection{E1 teatro y las canciones}

Apenas figuran en el Journal referencias al teatro inspirado por el nuevo régimen. Naturalmente, las nuevas autoridades no hubieran admitido las obras recientes en las que esas autoridades resultaran ridiculizadas. En agosto, se representa en el teatro madrileño del Príncipe "La ejecución del rey Luis XVI, el rey mártir". Al final aparece el busto de Riego y unos "genios" bajan del cielo para colocar en su cabeza una corona de roble y de laurel (11 de agosto).

A finales de noviembre, se ofrece a los espectadores gaditanos, con "una osadía impúdica", una obra en la que figuran un jefe político y el general Morillo ambos "echados en un retrete por el populacho" (15 de diciembre). Varias veces, el Journal señala que, en los desfiles por las calles de Madrid y de otras ciudades, se oye música instrumental o vocal. En este caso, la canción más popular que tendrá una larga descendencia es el "Trágala"102. La segunda canción popular es el "Himno de Riego", según el Journal.

102 El contenido en castellano y en francés se halla, por ejemplo, en la pequeña obra de A. Gil Novales, El Trienio liberal, op. cit., pp. 103-104. Pidió prestado el dato al general Saint-Yon, Les 
El 20 de agosto, en Madrid, a las nueve de la noche, varios individuos se pusieron a cantar el "Trágala" debajo de las ventanas de los guardias de corps encarcelados por acusados de haber insultado al pueblo durante los desórdenes que tuvieron lugar, hace unos meses, en la plaza del Palacio" (2-3 de septiembre).

\section{LA SITUACIÓN GENERAL}

Portándose con prudencia o quedándose a la expectativa, los articulistas del Journal, sólo a partir del verano, enjuician con una severidad que irá en aumento la situación del país, combinando a menudo varios temas: la política general, los enfrentamientos entre los partidos, el desorden generalizado y la economia. A principios de julio, el balance, calificado de catastrófico, se compone de los siguientes elementos: el trono carente de apoyo, "la fuerza pública sin subordinación", la inseguridad para las personas y los bienes y "la exageración en las máximas de libertad" (19 de julio)

Con el advenimiento del nuevo régimen han empeorado la desunión y los enfrentamientos entre los partidos que ascienden a seis cuando se incorpora al "clero" a pesar de no tener la categoria de partido. Los demás son los "serviles", los "cesantes" que estaban empleados durante el "régimen real" -extraña designación- los "afrancesados" considerados como unos "constitucionales moderados", los "constitucionales" partidarios de las Cortes y los "jacobinos" apegados a la "moda de 1793", es decir al periodo más violento de la Revolución francesa (3 de agosto). A principios del mes siguiente, se añaden otros aspectos en un balance igualmente negativo: la fiebre amarilla asola al país, lo devastan los bandoleros, lo recorren unas partidas armadas y ha estallado la "guerra civil en todos los sectores" (20 -21 de agosto).

A principios de septiembre, ocupa la primera fila la situación politica lamentable con la ineptitud de las Cortes y la inestabilidad de los ministerios (6 de septiembre). Más adelante, a mediados de noviembre, surge un término que volverá a aparecer varias veces: el de "disolución" empleado por un corresponsal español del Journal: "Se acerca el momento de la disolución de nuestra monarquía (...). Varias provincias se disponen a separarse de la capital para formar repúblicas federativas" (24 de noviembre). El término "disolución" aparece de nuevo, unos días después, en el "Extracto de una carta particular": "Todo camina claramente hacia una disolución del orden público y hacia un estado de anarquía como el de nuestras colonias de América" (8 de diciembre).

A mediados de ese mes, otro autor de una "correspondencia particular" acude al vocablo también espantoso de "guerra civil", a menudo asociado al de "anarquía": "Ha empezado la guerra civil y se perfila con sintomas terribles" (22 de diciembre). En el registro de las metáforas usadas para evocar el cataclismo inminente, figura la del volcán": es ya real "la amenaza de erupción" (17-18 de diciembre).

Huelga comentar las intenciones convergentes de los articulistas del Journal: para ellos, el régimen impuesto por los liberales con el apoyo de los "revolucionarios" no supone ninguna mejora o ventaja para los habitantes: ni la

deux Mina, Paris, 1840. No he visto el Diálogo imparcial sobre la canción del Trágala, trágala, trágala perro, Rosa Sanz, impresor, 1820. 
felicidad, ni la paz, ni la cohesión nacional, ni la consolidación de los derechos conseguidos en el pasado, ni el respeto de las tradiciones y, sobre todo, ni la sacralización de la religión, ni el culto rendido al rey Fernando, ni la defensa del régimen monárquico que ha de ser indestructible.

\subsection{La economia}

Predomina la impresión, previsible, de un metafórico naufragio general. En junio, un diputado declara: "No tenemos ni comercio, ni agricultura, ni industria" (13 de junio). Se insiste sobre todo en la gravedad de la situación financiera ${ }^{103:}$ "Las cajas están totalmente vacias" (27 de octubre). Los impuestos se cobran con dificultad (12 de agosto), porque "los labradores pretenden que, bajo el reinado de la libertad, no deben pagar nada y el gobierno no es lo bastante fuerte como para tomar medidas contra los individuos recalcitrantes" que no pagan, ni el diezmo cuya reducción no se ha hecho efectiva, ni las contribuciones territoriales, mientras que los comerciantes tardan en pagar el derecho de patente (8 de diciembre).

Por otra parte, la puesta en venta de los bienes de las órdenes monásticas suprimidas no tiene ningún éxito (11 de enero) y pasa lo mismo con la venta de los bienes nacionales ( 23 de febrero). Una breve alusión remite al empréstito del francés Laffitte que pierde gran parte de su valor (11 de enero). Varios meses después, el empréstito -no se precisa si se trata del de Laffitte-, está "paralizado" (sic) (13 de septiembre).

Una de las consecuencias del desorden financiero y del empobrecimiento de la población es que carecen de fondos los jefes politicos y los comandantes militares que no pueden pagar los sueldos de los soldados del ejército regular, de los jubilados y de algunos milicianos provinciales.

Con una exageración fomentada a la vez por la mala intención, la implícita denuncia y el desprecio, el autor anónimo de una "carta particular" llega a escribir, a finales del otoño, que el comercio está aniquilado, la industria, inexistente y el contrabando, enorme (29-30 de octubre).

\subsection{La epidemia de fiebre amarilla}

Se puede suponer que, si no hubieran intervenido unos médicos franceses, las noticias referidas a esa tragedia no hubieran sido tan frecuentes y detalladas en el Journal. En efecto, en una treintena de ocasiones está evocada con emoción y piedad ${ }^{104}$.

A principios de julio, se anuncia la aparición de la epidemia en el puerto de Barcelona, pero los lectores del Journal sólo se enterarán en el número del 20-21

103 Las "dificultades del Tesoro" están parcialmente evocadas por Jordi Nadal en El fracaso de la Revolución industrial en España, 1814-1913, Barcelona-Caracas-México, Ariel Historia, 1975 , p. 58.

104 Léon-François Hoffmann, En marge de l'histoire politique et littéraire de la France sous la Restauration: la peste à Barcelone, New Jersey, Université de Princeton / Paris, Presses Universitaires de France, 1964. Gaspar Feliu i Montfort, La clerecía catalana, op. cit., pp. 52-55. A. Gil Novales, El Trienio liberal, op. cit., pp. 39-40. 
de agosto. Poco tiempo después, las noticias son más bien tranquilizadoras, ya que la enfermedad ha provocado la muerte de tan sólo cuatro individuos.

Pero la inquietud no se ha extinguido porque, en Barcelona, se organiza la lucha contra esa "funesta plaga" con la puesta en servicio de un lazareto para recibir a los enfermos y las mercancias (2-3 de septiembre). También están prohibidas las comunicaciones entre Barcelona y el barrio popular de Barceloneta, a orillas del mar (10-11 de septiembre). La fiebre amarilla también se ha declarado en Málaga, Jerez, Córdoba, Puerto de Santa María y, un mes después, en Sevilla, Cádiz, Murcia, Alicante y Pamplona (17-18 de septiembre).

A finales de septiembre, las noticias procedentes de Barcelona son espantosas: a principios del mes, han muerto 50 personas. Las autoridades se han alejado de la ciudad; las tiendas y los talleres están cerrados; dos veces al dia, una carreta recorre las calles para recoger los cadáveres; se ha llevado a un convento a 2.000 habitantes de Barceloneta; y se ha formado un cordón sanitario a dos leguas de Barcelona (24-25 de septiembre). En octubre, no se ve a nadie en las calles y la ciudad yace en "una inmensa soledad"; están prohibidas las reuniones y sólo quedan abiertas las iglesias; mueren cada día entre 80 y 100 personas; la ciudad ha perdido la mitad de su población. Los horrores vinculados a la epidemia consisten en "asesinatos, envenenamientos, saqueos de casas y ocupación ilegal de casas desiertas"; los bandoleros armados de un puñal actúan en el campo, no lejos de Barcelona (8-9 de octubre).

En una carta muy posterior escrita en Barcelona a finales de noviembre se lee que la ciudad "no es más que el esqueleto de la que fue la más poblada de España" (3-4 de diciembre). En otra carta escrita en Zaragoza se anuncia que Tortosa, Mequinenza y Fraga están casi desiertas (17 de octubre). La población de Tortosa ha pasado de 12.000 habitantes a 4.000: "Las calles están cubiertas de cadáveres; todos mueren: varones, mujeres, niños, incluso animales" (3-4 de diciembre). La epidemia que, durante los primeros meses, sólo afectaba a Barcelona y a un sector de Cataluña, amenaza después a territorios lejanos situados al noroeste, según una información mencionada en el Mémorial béarnais: "En Navarra y Aragón, a manera de precaución, actúan unos campesinos armados para detener a los vagabundos procedentes de Cataluña" (13 de octubre).

También en Francia se toman precauciones: se impone la cuarentena a todo español que se aleja de su país y no se admite al norte de la frontera marítima ningún barco que proceda del mismo origen. Además, en noviembre, se crean lazaretos en Bayona y Socoa, en el litoral del País Vasco francés (18 de octubre).

En España, a principios de diciembre, "la salud pública va mejorando". Las obras caritativas disminuyen, pero la actividad de los talleres no ha reanudado y se multiplican los robos en las casas vacias. A finales del mes, llega el anhelado desenlace: "En Barcelona, la gente ya no se ocupa de la fiebre amarilla. Apenas se habla de ella. Los espíritus sólo están interesados por la política y perdura la fermentación" (27 de diciembre).

A mediados de noviembre, se alude por primera vez, en el Journal, a los médicos franceses que intervinieron en Barcelona: los más conocidos se llaman Pariset y Bally. En septiembre de 1821, Etienne Pariset (1770-1847) estuvo encargado de una misión en Barcelona. Convencido de que la fiebre amarilla se transmitía por contagio, pidió la creación de lazaretos donde se impondrían 
cuarentenas. Pariset podía haber hablado de André Mazet, joven discípulo suyo: ya en 1820, éste había publicado en París, al lado de Pariset, unas Observations sur la fièvre jaune, faites à Cadix en 1819, par MM. Pariset et Mazet, docteurs en médecine de la Faculté de Paris. Por su parte, François-Victor Bally (1775-1866) llegó a Barcelona en octubre. Después de una entrevista con el primer alcalde constitucional José Mariano de Cabanes, dirigió un grupo de cinco médicos. En 1823, con un colega, publicará en París una Histoire de la fièvre jaune observée en Espagne et particulièrement en Catalogne, dans l'année 1821. Entre $1856 \mathrm{y}$ 1866 se publicarán cuatro escritos dedicados a su vida y su labor. En el Journal del 30 de noviembre, la transcripción del texto de un tal doctor François dirigida a un amigo ocupa toda una columna; ese médico francés que pasará 37 dias en Barcelona, además de proporcionar noticias acerca de Pariset y de Bally, se muestra admirador de la activa vigilancia ejercida, durante la epidemia, por las autoridades barcelonesas; también resalta la generosidad de los ciudadanos con los pobres (26-27 de noviembre).

En una carta escrita en Barcelona a finales de noviembre se entrevé la colaboración del clero y de las autoridades civiles y militares: "El Te Deum pedido con mucha insistencia por unos barceloneses imprudentes se ha cantado con solemnidad en la catedral. Acompañó a las autoridades un destacamento de la guardia nacional a pie y a caballo" (12 de diciembre).

A partir del 10 de diciembre, "la salud va mejorando", como se lee en una carta escrita en Perpiñán. Se nota de paso que el ayuntamiento constitucional de Barcelona, evitando aludir, como los adversarios, a una correlación entre el advenimiento del régimen liberal y la aparición de la epidemia, prefiere alimentar el optimismo al idealizar el futuro: "El ayuntamiento se ha dirigido al pueblo con una proclama para anunciarle el final de la plaga que ha provocado un descenso numérico de la población y le ha predicho, con mucho énfasis, la mayor prosperidad, con tal de que no se aparte del camino trazado por la constitución" (12 de diciembre).

A principios de diciembre, cuando decrece la epidemia, se verifica una suscripción a favor de los residentes franceses enfermos que no pueden salir de Barcelona (3-4 de diciembre). Por su parte, los médicos franceses regresan a su país. Un poco antes, se señala en el Journal que varios diarios franceses han celebrado su noble y eficaz papel.

\section{EL MUNDO EXTERIOR VISTO DESDE ESPAÑA}

\section{Francia}

Según lo que se lee en el Journal, el pasado de Francia se recuerda poco al sur del Pirineo, a excepción de la sanguinaria Revolución, del infeliz Luis XVI y del aborrecible Napoleón. Como se podía prever, la Revolución, enfocada global y esquemáticamente por el Journal, se reduce a dos fechas: 1789 para su nacimiento y 1793-1795 con la Convención y su "máxima ferocidad". Como periodo, figura la admirable resistencia de la Vendée. Como realidad a la vez perceptible y simbólica, la bandera tricolor $y$ el cadalso se han hecho contradictorios e incompatibles.

De manera inédita, una comparación entre "la constitución francesa de 1791 y la de España en 1812" figura en un diario alemán publicado en Augsbourg, 
título traducido al francés por Gazette Universelle. Tal como se lee en el Journal en el que no es frecuente el juego conceptual irónico, las dos constituciones -la francesa y la española-, "monárquicas y anárquicas (sic) establecen una asamblea soberana que representa la voluntad concentrada y dictatorial del pueblo" (25 de enero).

A propósito de la Revolución francesa se advierte que los cabecillas serviles Merino y Zaldivar son enjuiciados peyorativamente por los liberales españoles, a semejanza de lo que hacian, en 1795, los comisarios de la Convención cuando juzgaban a los vandeanos de manera despiadada. Además, los liberales españoles son culpables de favorecer la publicación de "todos los libros que la impiedad y la anarquía han engendrado en Francia en 1795" (19 de agosto). Acercándose a la actualidad, un articulista del Journal define los constitucionales franceses como unos partidarios determinados de la Carta ("Charte" en francés) y "su evangelio político no es sino el Contrato Social (de Jean-Jacques Rousseau), mal leído y mal comprendido" (5 de enero).

En la sesión del 12 de febrero de la "Chambre des députés", La Fayette, cuya imagen va a salir embellecida, recordó que "la Asamblea Constituyente había establecido como principio que Francia no emplearía nunca sus fuerzas para encadenar la libertad de algún pueblo". Por eso, los acontecimientos de España y de Portugal llenaron los corazones -suponemos, únicamente los de los liberalesde alegría (12-13 de febrero).

A principios de abril, se menciona, en el Journal, un cartel manuscrito, aparecido en Lille, que recogía una alusión a la reforma institucional española y que rezaba lo siguiente:

“¡Viva la gloriosa escarapela tricolor!

¡Viva la constitución de las Cortes!

¡Vivan los napolitanos!

¡Viva la gran nación! (2-3 de abril)”.

En el otoño, el ciudadano francés citado en una "carta particular" que más ocupa la actualidad en España es Cugnet de Montarlot, escritor, consejero de Riego, que llevaba algún tiempo residiendo al sur del Pirineo. Como lo aclara A. Gil Novales, ese militar refugiado en Zaragoza, "habia concebido una disparatada empresa para restaurar en Francia la Constitución de 1791. Fue detenido el 4 de septiembre"105. La información proporcionada por el Journal es más sustancial: "El señor Cugnet de Montarlot, ex redactor del Nain Jaune (el Enano Amarillo), cae en el ridículo al titularse general en jefe de los ejércitos constitucionales y presidente del Imperio francés". En una de sus proclamas estrambóticas, declaró que "la constitución de 1791, a excepción de la autoridad real, está proclamada provisionalmente" (17-18 de septiembre).

Cuando, a principios de septiembre, se menciona al embajador de Francia, el conde de Montmorency-Laval, irrumpe en la actualidad su futuro sucesor, digno de alabanza, que se llama a secas "La Garde" o "Lagarde"106 (15 de septiembre).

105 A. Gil Novales, El Trienio liberal, op. cit., p. 41.

106 Auguste Pelletier de Lagarde (1780-1834) ha sido ministro plenipotenciario en Baviera en 1816 y será embajador en España en 1822 (fecha dudosa). Recibirá el título de barón en 1823. 
Según los "clubistas", La Garde ejerce una gran influencia sobre el rey Fernando con quien mantiene frecuentes y largas conversaciones en San Ildefonso. Pero Le Régulateur, diario revolucionario escrito en francés en España, asestará un duro golpe a La Garde, acusándole claramente de conspirar contra el sistema constitucional de España (22 de septiembre). En la misma época, en el transcurso de unos disturbios callejeros en Madrid atribuidos a los liberales exaltados, "la residencia del conde de Lagarde, ministro plenipotenciario de Francia, fue saqueada". Huelga añadir que, para esos militantes, el gobierno de París inspiraba, si no el odio, por lo menos, la inquietud.

Varios meses después, en la primavera, circula un rumor calificado de absurdo por los realistas, rumor según el cual unas fuerzas militares francesas se habían acercado a la frontera, quizá con la intención de franquearla. Por eso, las autoridades liberales españolas habian lanzado -dato difícil de confirmar- la alerta en Guipúzcoa, Álava, Vizcaya y Navarra (26-27 de marzo). Lo que sí se puede confirmar es que, pronto, las autoridades madrileñas, sabiéndose juzgadas con desconfianza u hostilidad por el gobierno parisino, temieron una invasión extranjera destinada a derribarlas.

\section{Europa y América}

Se pasará por alto aquí la frecuente presencia de párrafos que conciernen a Inglaterra, Alemania, Austria, Rusia, etc. En cuanto a Portugal e Italia, son muy pocas las alusiones a la intervención directa o indirecta del gobierno español.

En 1821, se publicó en París y Ruán la obra de abate de Pradt, L'Europe et l'Amérique en $1821^{107}$ en la que el autor calibra acertadamente la repercusión de los acontecimientos españoles de 1820 tanto en Europa como en América: "La revolución de España provocó el nacimiento, seis meses después, de la revolución de Nápoles; reunidas las dos, tres meses después, han hecho las del Piamonte, de Madeira, de Brasil y de América".

A principios de enero, se transcribe, en el Journal, la opinión de un corresponsal en Hamburgo, susceptible de despertar el interés de los lectores: "Las revoluciones de España, Rusia, Austria y Prusia llenan de inquietud todas las potencias que han luchado contra la revolución" (7 de enero). Según el diputado "Moreno Guerra," "la vanguardia constitucional está en Nápoles, el centro en España y la retaguardia en Portugal" (5 de abril). Ese José María Moreno de Guerra y Navarro, en el Diario Gaditano del $1^{\circ}$ de abril, había escrito que "la causa de Nápoles era la nuestra", es decir española108. En el Journal, aparecen las repetidas alusiones, a veces sin acentuada malignidad, a la insurrección en Nápoles y en el Piamonte, calificada ésta de "eminentemente liberal". A principios de septiembre, los liberales españoles aluden a una alianza, supuestamente deseada, entre España e Inglaterra (12 de septiembre).

Respecto a los acontecimientos en América, la primera noticia publicada en el Journal, por lo menos a partir de enero de 1821 , procede de unas cartas escritas en Buenos Aires, anunciadoras de que "más de quinientas personas han muerto en la revolución que estalló en aquella ciudad. He aquí un nuevo ejemplo

107 A Paris, chez Béchet aîné; à Rouen, chez Béchet.

108 Gil Novales, Diccionario, op. cit., t. II, pp. 2080-2086. 
de lo mucho que cuestan las revoluciones y un escarmiento para los que no tienen la cordura de temerlas" (25 de enero).

La sorpresa que nos reserva el Journal del año 1821 es la importancia concedida a Pablo Morillo y Morillo, futuro conde de Cartagena. Puede ser que hayan intervenido a favor de su imagen sus convicciones absolutistas y el recuerdo de su enérgica campaña cuya finalidad era la reconquista por la metrópoli de las provincias americanas insurrectas. Efectivamente, entre 1814 y 1820, había luchado en Venezuela y Colombia. En una fecha exacta ignorada, regresa a España en 1821 y llega a París a finales de marzo después de una estancia en Madrid: "El general Morillo ha demostrado eminentes talentos en América donde luchó, durante 6 o 7 años, con un puñado de hombres, contra las fuerzas de las provincias de Venezuela y del reino de Nueva Granada" (25 de marzo). Se ignora cuándo volvió nuevamente a España. Después de los disturbios en Madrid de 20 y 21 de agosto, presenta su dimisión que será rechazada por el rey. El general ha redactado una proclama en la que justifica su intervención y afirma que "su sable no ha salido de la vaina" (8 de septiembre). En una carta a los editores de El Espectador, redactada el 24 de agosto, para no ser tachado de aborrecible absolutista, se declara "amigo de la libertad". Unos días después, pone una condición para su dimisión: sólo la aceptará cuando se le declare inocente (15 de septiembre). En el verano de 1821, los "revolucionarios" españoles no le pierden de vista y "piden su cabeza", porque se sospecha que mantuvo relaciones con Bolivar. Efectivamente, Morillo firmó con él un armisticio en el otoño de 1820. Ya se le pierde de vista en el Journal y no se aludirá a sus escritos y a las réplicas que suscitaron. A mediados de octubre de 1821, el diario anuncia que el rey ha nombrado edecán al general Morillo, conde de Cartagena (27 de octubre). A lo largo de los años siguientes, no sé si el Journal mencionó su actuación, pero conviene señalar que el público francés interesado por los sucesos en las antiguas colonias españolas de América podrá acceder, en 1826, a los Mémoires du général Morillo, comte de Carthagène, marquis de la Puerta, relatifs aux principaux événements de ses campagnes en Amérique de 1815 à 1821 (...), traduits de l'espagnol109. En esas Memorias figuran en los "Documentos justificativos" dos cartas de Bolivar y media docena de escritos del conde de Cartagena.

Al margen de los fragmentos biográficos relativos a Morillo, el silencio del Journal se prolonga hasta septiembre cuando se anuncia que "el gobierno español parece determinado a desplegar un nuevo esfuerzo para dominar de nuevo las provincias septentrionales de la América meridional". En consecuencia, unos barcos de guerra hacen rumbo hacia Caracas (12 de septiembre).

El 3 de septiembre, han salido de Madrid para dirigirse hacia París los diputados enviados a la capital de España por Bolivar para negociar la paz, pero fueron acusados de maniobras sospechosas (17-18 de septiembre).

Los articulistas del Journal, incapaces de profundizar en el análisis de los sucesos en los antiguos territorios españoles de América, se contentan con expresar su sorpresa al enterarse de que los habitantes de allí siguen apegados al

109 Los traductores se llaman Ernest de Blosseville y Messonnier de Valcroissant - Obra publicada "A Paris, chez P. Dufart". 
rey Fernando, pero atreviéndose a pedir la destitución de los virreyes, por ejemplo en México y en el Perú (11 de octubre).

Un mes después, en una "Correspondencia particular" fechada en Madrid el 22 de noviembre, se subraya la importancia del "gran acontecimiento de la independencia de México" encabezada por el virrey O’Donojú". Efectivamente, su proclama en Tacubaya, el 17 de septiembre, ha sido la última de un virrey en México110 y "la noticia ha producido en Madrid la sensación más fuerte y alimentado todas las conversaciones" (5 de diciembre). En diciembre, una carta escrita en La Habana a finales de octubre saca del anonimato al mejicano Agustín Iturbide, nacido en Valladolid (hoy Morelia), que "consintió en la independencia del país" (12 de diciembre).

En el número del 29 de diciembre del Journal, sale a su vez del anonimato el gaditano Juan Ruiz de Apodaca, virrey de Nueva España entre 1815 y 1821 y, luego, jefe político que será depuesto de su cargo en julio de $1821^{111}$. Como se lee en el Journal, "todo México está definitivamente perdido para España". Ruiz de Apodaca, que comparte esa opinión, "pretende que Iturbide va a hacerse proclamar emperador". Efectivamente, será proclamado "regente emperador" bajo el nombre de "Agustín $1^{\circ}$ " (29 de diciembre).

Del Journal no se podia esperar, acerca de España, informaciones esenciales, meditadas, incontrovertibles y neutrales, dada la orientación ideológica del diario, ya que era, como se ha dicho, monárquico, conservador, contrarrevolucionario y clerical. Pero es interesante por el sinnúmero de noticias referidas al país vecino, algunas conocidas cuando se trata de traducciones de textos impresos, de discursos pronunciados por el rey Fernando o por diputados, de proclamas y de cartas personales. Otras noticias son más bien intrascendentes, anecdóticas, pero reveladoras de un clima muy distinto del que reinó durante el Sexenio 1814-1820.

Esa profusión de pequeños datos incita a abandonar la idea de que la revolución de 1820 provocó un cisma únicamente entre liberales y antiliberales, puesto que el sondeo de las opiniones ha puesto de relieve, en el Journal, un trastorno que fomentó un gran número de escisiones en el seno de los partidos, de los militares, del clero, de la población urbana y del campesinado.

Como se podía esperar, el Journal se niega terminantemente a sostener el nuevo régimen instaurado por los partidarios de Riego y se va fortaleciendo la impresión de que, en el transcurso de sólo un año, ha ido en aumento la decepción o el descontento de la mayoría de los habitantes. Pero no se trasluce la idea de que muchos de ellos anhelan la intervención armada, esperada salvadora, de los ex invasores napoleónicos de 1808 o de los lejanos descendientes de la revolución parisina de los años 1789-1795, la cual había acarreado el asesinato del monarca y la utilización del cadalso. La probable sorpresa, no para los lectores del Journal de 1821, sino para los lectores actuales, es el descubrimiento

110 Gil Novales, Diccionario, op. cit., t. II, p. 2202.

111 Juan Ruiz de Apodaca y Eliza, conde del Venadito: Gil Novales, Diccionario, op. cit., t. III, pp. 2702-2703. 
de que una gran parte de habitantes acogerá, posiblemente con alegría o alivio, a los "Cien Mil Hijos de San Luis".

Con todo, perdura la impresión, alentadora para el sector de la historiografia antifranquista, de que, con tantos desfiles, agitación callejera, discursos, artículos en la prensa, proclamas, canciones, los primeros años del Trienio han fomentado una amplia toma de conciencia ideológica colectiva, no limitada a una élite. Otra sorpresa para los lectores actuales del Journal es la pobreza de la información referida a las opiniones y a la actuación política de la aristocracia y de la burguesía. En cambio, después de 1833, los liberales celebrarán el Trienio por el advenimiento del pueblo como un determinante actor político, y ello sin contentarse con rendir culto a Riego y cantar el "Trágala".

A pesar de la denuncia, en el Journal, del régimen instaurado en 1820, no se transparenta, del lado francés, ninguna generalizada hispanofobia acompañada de desprecio o de desconfianza. Lo ilustra la frecuencia de las referencias al país vecino, pero habrá que esperar la intervención victoriosa de las tropas del duque de Angulema para que se implante en Francia "la moda española", con la invitación a efectuar visitas turísticas al sur del Pirineo, valorar la música folklórica, explorar la obra de Cervantes y admirar la pintura de Velázquez y del Greco.

Fecha de envio / Submission date: 12/02/2020

Fecha de aceptación / Acceptance date: 25/04/2020 